\title{
Survival and Persistence of Foodborne Pathogens in Manure-Amended Soils and Prevalence on Fresh Produce in Certified Organic Farms: A Multi-Regional Baseline Analysis
}

\section{OPEN ACCESS}

Edited by:

Karl Matthews,

The State University of New Jersey,

United States

Reviewed by:

Keith Warriner,

University of Guelph, Canada

Lisa Gorski.

Agricultural Research Service,

United States

*Correspondence:

Alda F. A. Pires

apires@ucdavis.edu

Specialty section: This article was submitted to

Agro-Food Safety,

a section of the journal

Frontiers in Sustainable Food Systems

Received: 01 March 2021 Accepted: 08 September 2021

Published: 15 October 2021

Citation:

Ramos TDM, Jay-Russell MT, Millner PD, Baron JN, Stover J,

Pagliari P, Hutchinson M, Lilley J, Rowley N, Haghani V, Aminabadi P, Kenney A, Hashem F,

Martínez-López B, Bihn EA, Clements DP, Shade JB, Sciligo AR and Pires AFA (2021) Survival and Persistence of Foodborne Pathogens

in Manure-Amended Soils and

Prevalence on Fresh Produce in

Certified Organic Farms: A Multi-Regional Baseline Analysis. Front. Sustain. Food Syst. 5:674767. doi: 10.3389/fsufs. 2021.674767
Thais De Melo Ramos ${ }^{1}$, Michele T. Jay-Russell ${ }^{2}$, Patricia D. Millner ${ }^{3}$, Jerome Nicholas Baron ${ }^{1,4}$, James Stover ${ }^{1}$, Paulo Pagliari ${ }^{5}$, Mark Hutchinson ${ }^{6}$, Jason Lilley ${ }^{6}$, Nicholas Rowley ${ }^{6}$, Viktoria Haghani ${ }^{1}$, Peiman Aminabadi ${ }^{2}$, Annette Kenney ${ }^{7}$, Fawzy Hashem ${ }^{7}$, Beatriz Martínez-López ${ }^{4}$, Elizabeth A. Bihn ${ }^{8}$, Donna P. Clements ${ }^{8}$, Jessica B. Shade ${ }^{9}$, Amber R. Sciligo $^{9}$ and Alda F. A. Pires ${ }^{1 *}$

${ }^{1}$ Alda Pires Laboratory, University of California, Davis, Department of Population Health and Reproduction, School of Veterinary Medicine, Davis, CA, United States, ${ }^{2}$ Western Center for Food Safety, University of California, Davis, Davis, CA, United States, ${ }^{3}$ Environmental Microbial and Food Safety Laboratory, U.S. Department of Agriculture, Agricultural Research Service, Beltsville, MD, United States, ${ }^{4}$ Center for Animal Disease Modeling and Surveillance, Department of Medicine and Epidemiology, School of Veterinary Medicine, University of California, Davis, Davis, CA, United States, ${ }^{5}$ University of Minnesota, Department of Soil, Water, and Climate, Southwest Research and Outreach Center, Lamberton, MN, United States, ${ }^{6}$ University of Maine Cooperative Extension, Waldoboro, ME, United States, ${ }^{7}$ Department of Agriculture, Food and Resource Sciences, University of Maryland Eastern Shore, Princess Anne, MD, United States, ${ }^{8}$ Produce Safety Alliance, Department of Food Science, Cornell University, Geneva, NY, United States, ${ }^{9}$ The Organic Center, Washington, DC, United States

Biological soil amendments of animal origin (BSAAOs), including untreated (e.g., raw or aged manure, or incompletely composted manure) and treated animal products (e.g., compost), are used for crop production and as part of soil health management. Application of BSAAO's must be done cautiously, as raw manure commonly contains enteric foodborne pathogens that can potentially contaminate edible produce that may be consumed without cooking. USDA National Organic Program (NOP) certified production systems follow the 90-or 120-day interval standards between applications of untreated BSAAOs and crop harvest, depending on whether the edible portions of the crops are in indirect or direct contact with the soil, respectively. This study was conducted to evaluate the survival of four foodborne pathogens in soils amended with BSAAOs and to examine the potential for bacterial transfer to fresh produce harvested from USDA NOP certified organic farms (19) from four states. Only 0.4\% (2/527) of produce samples were positive for $L$. monocytogenes. Among the untreated manure and compost samples, $18.0 \%(42 / 233)$ were positive for at least one of the tested and culturable bacterial foodborne pathogens. The prevalence of non-O157 STEC and Salmonella in untreated manure was substantially > that of E. coli $\mathrm{O} 157: \mathrm{H} 7$ and L. monocytogenes. Of the 2,461 soil samples analyzed in this study, $12.9 \%$ (318) were positive for at least one pathogen. In soil amended with untreated manure, the prevalence of non-0157 STEC 
[7.7\% (190) and L. monocytogenes (5.0\% (122), was > that of Salmonella (1.1\% (26)] or E. coli $\mathrm{O} 157[0.04 \%$ (1)]. Foodborne pathogen prevalence in the soil peaked after manure application and decreased significantly 30 days post-application (dpa). However, non-O157 STEC and L. monocytogenes were recovered from soil samples after 90 and 120 dpa. Results indicate that produce contamination by tested foodborne pathogens was infrequent, but these data should not be generalized outside of the specific wait-time regulations for organic crop production and the farms studied. Moreover, other sources of contamination, e.g., irrigation, wildlife, environmental conditions, cropping and management practices, should be considered. This study also provides multi-regional baseline data relating to current NOP application intervals and development of potential risk mitigation strategies to reduce pathogen persistence in soils amended with BSAAOs. These findings contribute to filling critical data gaps concerning occurrence of fecal pathogens in NOP-certified farming systems used for production of fresh produce in different US regions.

Keywords: biological soil amendments, vegetables, STEC, Listeria, monocytogenes, Salmonella

\section{INTRODUCTION}

Healthy fertile soils are essential for resilient crop production and supporting the global ecosystem. They positively contribute to soil water retention, support a diversity of organisms vital to decomposition and nutrient cycling, provide crops with essential nutrients, and can maintain carbon stores, contributing to global climate change mitigation. Building soil health is one of the strongest ways to protect against drought and flooding, as well as increasing the efficiency of nutrient cycling and crop yield (Ozlu and Kumar, 2018; Tautges et al., 2019). One of the most effective ways to build and maintain soil health is through the use of biological soil amendments that supply organic matter and essential nutrients for plant growth. Biological soil amendments can be plant-or animal-based and include green manures (e.g., leguminous cover crops that are terminated early and turned into the soil for nutrients), composts made from recycled plant material and/or animal manure, and raw manures (Rosen and Allan, 2007; Sharma and Reynnells, 2016).

Biological soil amendments of animal origin (BSAAOs) are especially popular because of their high nutrient content and low cost. They can improve several soil characteristics, including available nutrients, water retention, permeability, water infiltration, drainage, aeration, and structure (Rosen and Bierman, 2005; Rosen and Allan, 2007; Sharma and Reynnells, 2016), and thus, are a valuable component of sustainable farming. BSAAOs are especially important to organic farmers. Organic agriculture takes an environmentally balanced approach to agriculture, focusing on diverse crop rotations and cover crops, while restricting the use of synthetic inputs, such as fertilizers, pesticides, antibiotics, growth hormones, or sewage sludge (Rosen and Bierman, 2005; Rosen and Allan, 2007; United States Department of Agriculture National Organic Program, 2011a,b). BSAAOs are critical for organic farming to manage soil fertility because synthetic nitrogen fertilizer (ammonium) is prohibited and USDA national organic standards require growers to improve soil health over time, which can be accomplished by using BSAAO (United States Department of Agriculture National Organic Program, 2011a). In addition, the use of BSAAOs in organic production provides a means of beneficial use manure from livestock premises (Rosen and Allan, 2007; Sharma and Reynnells, 2016).

The use of raw manure, a BSAAO, must be done with care, as raw manure frequently contains enteric pathogenic bacteria (e.g., E. coli O157:H7, Salmonella spp., Listeria spp., and Campylobacter spp.). Raw manure application introduces a potential source of pathogen contamination (Hutchison et al., 2005; Sharma and Reynnells, 2016; Alegbeleye et al., 2018; Sharma et al., 2019) through direct or indirect contact, which can expose fruits and vegetables to pre-harvest microbial risks (Olaimat and Holley, 2012; Park et al., 2012; Alegbeleye et al., 2018). This risk exists in both organic and conventional production. However, because organic farms are limited in the type of soil-building and fertilizer inputs allowable under the NOP, they may rely on some form of BSAAOs. Identifying precisely, where these contamination risks can be prevented is complex in open-field systems with multiple potential routes and sources of microbial contamination, such as contaminated agricultural water (for irrigation and/or from flood/runoff), sick workers, fecal deposition from intruding domesticated or wild animals, and contaminated pre-harvest equipment (e.g., used for raw manure application/incorporation) (Olaimat and Holley, 2012; Park et al., 2012; Alegbeleye et al., 2018).

In an effort to prevent microbial contamination and reduce foodborne illnesses associated with fresh produce consumption, both conventional and organic farming operations are covered by the U.S. Food and Drug Administration's (FDA) Food Safety Modernization Act (FSMA) Produce Safety Rule (PSR), which requires comprehensive, science-based preventive controls across the food supply chain, including the growing, harvesting, packing, and holding of fresh fruits and vegetables (FDA, 2018). The rule establishes standards for agricultural water, 
animal-based soil amendments, domesticated and wild animal intrusion, employee health and hygiene, and building and equipment sanitation (FDA, 2015, 2018). The PSR categorizes BSAAO as treated and untreated; "untreated" BSAAO have not been processed to adequately reduce the prevalence of microorganisms of public health significance (FDA, 2015, 2018). The PSR requires that untreated BSAAO must be handled, conveyed, and stored in a manner that does not contact covered produce during application and minimizes the potential for contact with covered produce after application (FDA, 2015, 2018). Currently, however, the FSMA PSR has not established a minimum application interval between applying an untreated BSAAO (e.g., raw manure) and harvest. The proposed draft of the FSMA PSR, released by FDA in 2014, included a 9-month interval between applying untreated BSAAO and harvest (FDA, 2015, 2018), however that decision on implementation of specific time intervals was deferred in the final FSMA PSR released on Nov 27, 2015 until a science-based risk assessment could be conducted (FDA, 2015, 2016). Presently, FDA through the FSMA PSR does not object to the USDA National Organic Program (NOP) regulation of a 90-or 120-day interval between applications of untreated BSAAO and harvest of crops (FDA, 2015, 2018), while additional data is collected for detailed risk analysis. Growers are encouraged to use current NOP application intervals.

These NOP required application intervals may be why, despite the prevalence of manure use in organic operations (Pires et al., 2018), only a small proportion of foodborne illness outbreaks have been attributed to organic produce in the United States (Harvey et al., 2016; Dewey-Mattia et al., 2018; Pradhan et al., 2019), with one study reporting a link between vegetable contamination and horse manure in a home garden (Jay-Russell et al., 2014).

The current NOP imposes a 90-or 120-day wait period between application of animal-based soil amendments (i.e., raw manure and untreated manure) and time of crop harvest, based on whether the crop comes into direct contact with the soil or not, respectively (United States Department of Agriculture National Organic Program, 2011a,b). This time-interval between application and harvest was developed under production cycle criteria and not on microbial contamination risk (Natvig et al., 2002; Ingham et al., 2005). Actually, few studies have reported the survival of Salmonella spp. and non-O157 STEC in soil amended with untreated manure under natural conditions, and most of those were in conventionally managed fields ( $\mathrm{Gu}$ et al., 2018, 2019; Sheng et al., 2019). Survival of foodborne pathogens in soil amended with manure varies greatly (Natvig et al., 2002; Franz et al., 2005; Ingham et al., 2005; You et al., 2006). Under experimental conditions, Salmonella spp. can survive up to 332 days in manure-amended soils (You et al., 2006), and E. coli $\mathrm{O} 157: \mathrm{H7}$ can survive up to 56 days in soil amended with inoculated manure (Franz et al., 2005). While in naturally contaminated manure studies, Salmonella was isolated 4 months after soils were amended with poultry litter ( $\mathrm{Gu}$ et al., 2019); whereas no Salmonella were detected in soil 2 to 4 months post-dairy cattle manure application (Sheng et al., 2019).

The rationale for NOP application intervals was based on crop production cycles rather than survival and transfer of foodborne pathogens from soil to fresh produce systems (Sharma and Reynnells, 2016; Ramos et al., 2019). These application intervals can be burdensome for organic farmers with complex crop rotations and polycultures, particularly when short-season crops are included in the mix. A survey conducted by the Organic Trade Association (OTA) and Washington Department of Agriculture in 2013 found that nearly $75 \%$ of the 310 respondents reported that even a 45 day wait period (for compost) would either moderately effect or prevent crop rotation and diversity (Organic Trade Association, 2015). The extended application intervals for untreated soil amendments may be more difficult to incorporate into crop production than those recommended for treated soil amendments. A recent survey reported that BSAAOs were applied by $46.8 \%$ of the NOP certified organic producers growing crops that are typically consumed fresh; and $58 \%$ of the producers reported the use of raw manure as a soil amendment (Pires et al., 2018). Moreover, Ramos et al. (2019) also reported that untreated BSAAO are very important regionally for certified organic producers, but on-farm manure management practices related to raw manure use were not uniform (Ramos et al., 2019). While the environmental benefits of using BSAAOs are well understood, if farm operations are impeded by these application intervals, then they may choose to replace BSAAOs with soil amendments that are not manure-based (i.e., green waste-based), or that have been treated to minimize risk (Karp et al., 2016; Baur, 2020). These studies explain the importance of raw manure use in organic fresh produce and the need to implement standard practices that are adequate in reducing the risk of potential crop contamination (Pires et al., 2018; Ramos et al., 2019).

To assess whether the USDA NOP 90-and 120-day application interval criteria was sufficiently long enough to reduce the food safety risks in organic systems, this study was design to evaluate the potential transfer of culturable, bacterial foodborne pathogens to fresh produce from fields amended with untreated manure on NOP-certified farms. We accomplish this by (1) assessing the prevalence of four major foodborne pathogens (non-O157 STEC, E. coli O157:H7, Salmonella spp, and L. monocytogenes) in untreated manure from various animal sources, (2) evaluating the prevalence and persistence of four culturable and tested bacterial foodborne pathogens in amended soils with untreated manure across time, and (3) evaluating the presence of bacterial foodborne pathogens in fresh produce from fields amended with untreated manure. The overall objective of this effort is to address the gap on prevalence and persistence of foodborne pathogens from raw (untreated) manure incorporated into soil and their transfer to fresh produce, thereby providing critical scientific evidence to inform NOP and FSMA PSR standards about wait periods between manure application and harvest.

\section{MATERIALS AND METHODS}

\section{Farm Selection Criteria}

Certified USDA-NOP farms from four states (California, Minnesota, Maine, and Maryland) were selected, states which represent $70 \%$ of the national produce production (e.g., 
vegetables, melons) (United States Department of Agriculture National Agricultural Statistics Service, 2014). Produce from these states frequently have been associated with outbreaks linked to fresh produce in recent years (Center for Disease Control, 2016), and represent the diversity of farms growing fresh produce with different environments, soils, landscape conditions, management practices, and produce types. Recruitment was conducted by personal invitation, email, phone, or personal visit through various outlets (e.g., listservs, farmer associations, extension networks). Farms were enrolled based on the following criteria: (1) certified USDA-NOP fresh produce farm, (2) use of untreated manure (i.e., raw manure or untreated manure) of cattle, horse or poultry sources in produce fields, (3) grow at least one of the following fresh crops: leafy greens (e.g., lettuce, spinach, kale), root vegetables (e.g., carrots, radish, potato) and/or fruits (e.g., tomatoes, cucumbers, peppers), (4) willingness to participate and provide biological samples (raw manure, soil, irrigation water, and fresh produce) and information about their on-farm management practices and location. Farms were followed up for two growing seasons. Sixteen farms were enrolled in the 1st year (2017) and 18 farms were enrolled in the 2nd year (2018) of this 21-month longitudinal and multi-regional field study that took place from March 2017 to December 2018. Farms received compensation for participating in this study. Farmers were asked to complete a questionnaire regarding demographics, farm-management practices, irrigation practices, manure use, and soil health. The questionnaire can be shared upon request.

\section{Field Sample Collection}

In this 21 month longitudinal study, 19 farms were sampled periodically from March 2017 to December 2018 using the following scheme in each growing season: (1) untreated manure, compost and soil were sampled before manure application (d0A, baseline), (2) soil samples were collected after manure incorporation ( $\mathrm{d} 0 \mathrm{~B})$ and monthly for a total of seven times $(30,60,90,120,150$ and 180-days post manure application) for each crop cycle, (3) fresh produce was collected two to three times (between 90 to 150 days post-manure application), and (4) irrigation water was sampled once during the harvesting period. A total of five composite raw/untreated manure or compost samples were collected from manure piles using a shovel and a sterile scoop (Fisher Scientific, Hampton, NH). Each composite sample was collected from five separate spots and different depths in the manure pile with at least 90-100 g total per composited sample. For each type of fresh produce and manure type, four composite soil samples (five subsamples each) were collected using a stainless-steel soil core sampling probe 6 inches $(15.2 \mathrm{~cm})$ deep from the soil surface (Strawn et al., 2013b). Four fresh produce samples ( $\sim 100 \mathrm{~g}$ for leafy greens, and 150$200 \mathrm{~g}$ for fruits and root vegetables) were collected throughout the selected field in a serpentine pattern, and twice or three times depending on availability (d90, d120 and d150 days), using sterile scissors and aseptically transferred into sterile Whirl-Pak bags (Nasco, Modesto, CA). Samples were transported or shipped to the laboratory with ice packs. Nitrile gloves (Micro flex ${ }^{\mathrm{TM}}$ $\mathrm{XCEED}^{\mathrm{TM}}$ Powder-Free Nitrile, Fisher Scientific), were used, and changed and scissors, soil cores, and other sampling equipment were sanitized between samples to prevent cross-contamination. However, due to the snow cover in winter, not all eight sampling visits were carried out for each growing season. Field researchers blinded private property identifying data (i.e., owner name, farm name, address) from the laboratory by using an alphanumeric code assigned to each location.

A maximum of two irrigation water samples ( $1 \mathrm{~L}$ each) were collected from the source (e.g., agricultural well, pond, reservoir, lagoon, creek) at each farm for each growing season. Prior to sampling, well water taps or the open end of the irrigation line were disinfected with $70 \%$ ethanol and allowed to run freely for 1 min (Pagadala et al., 2015). Surface water from ponds or creeks was collected from the surface of the source, taking care not to disturb any sediment. When necessary, a sterile Nalgene bottle (Thermo Scientific, Rochester, NY) was attached to a pole to reach the water. All samples were collected by one of the research team members, sealed, transported in coolers with ice packs, and transported or shipped to the laboratory for microbiological analysis within $48 \mathrm{~h}$ of collection. Over the course of the study, a total of 3,260 samples were collected, including 2,461 soil samples, 527 produce samples at harvest, 233 untreated manure and compost samples, and 39 water samples.

\section{Sample Preparation}

\section{Soil, Compost and Manure Sample Preparation}

Samples were prepared using modified versions of protocols previously described (Paton and Paton, 1998; Cooley et al., 2013, 2014; Atwill et al., 2015; Food and Drug Administration, 2018; Pires et al., 2019). All samples were used for three separate enrichment schemes to allow for isolation and identification of non-O157 STEC, L. monocytogenes, E. coli O157:H7, Salmonella spp, and generic E. coli. For each manure, compost, and soil sample collected, $30 \mathrm{~g}$ of sample were weighed and transferred to $24 \mathrm{oz}$ Whirl-Pak bags (Nasco, Modesto, CA) containing $270 \mathrm{ml}$ of Tryptic Soy Broth (TSB) (1:10 dilution). The TSB non-selective enrichment cultures were used for non-O157 STEC, E. coli O157:H7, and Salmonella isolations. $25 \mathrm{~g}$ of each sample collected (manure, compost, and soil) were also added to a $24 \mathrm{oz}$ Whirl-Pak bag containing $225 \mathrm{ml}$ of Listeria Enrichment Broth (LEB) (1:10 dilution). Bags with both enrichments (TSB and LEB) were manually massaged for $1 \mathrm{~min}$ to homogenize the enrichments. Once all enrichments were prepared, the TSB and LEB Whirl-Pak bags were separated for their respective incubations. TSB WhirlPak bags were incubated at $25^{\circ} \mathrm{C}$ for $2 \mathrm{~h}$ followed by a $42^{\circ} \mathrm{C}$ incubation for $8 \mathrm{~h}$ shaking at $100 \mathrm{rpm}$. Then, samples were held at $6^{\circ} \mathrm{C}$ with no shaking until use for further enrichments and isolations of non-O157 STEC, E. coli O157:H7, and Salmonella spp. The LEB bags were incubated for $18 \mathrm{~h}$ at $30^{\circ} \mathrm{C}$ with $100 \mathrm{rpm}$ shaking (Multitron programmable shaking incubator (Eppendorf, Hauppauge, NY, USA), then held at $6^{\circ} \mathrm{C}$ with no shaking until use for $L$. monocytogenes enrichment and isolation.

\section{Irrigation Water Sample Preparation}

Fecal indicator bacteria $(100 \mathrm{ml}, 10 \mathrm{ml}, 1 \mathrm{ml}$ and $1 \mu \mathrm{l})$, specifically generic E. coli and non-E. coli fecal coliforms, were enumerated 
from each water sample using standard membrane filtration techniques (Partyka et al., 2018). Each sample was homogenized and poured through a $0.45 \mu \mathrm{m}$ nitrocellulose filter and placed on CHROMagar ECC (CHROMagar Microbiology, Paris, France), then incubated at $42^{\circ} \mathrm{C}$ for $18-24 \mathrm{~h}$. E. coli and non-E. coli coliforms colonies were counted and reported as colony forming units (CFU). $1 \mathrm{~L}$ of water was also poured through a $0.45 \mu \mathrm{m}$ nitrocellulose filter and placed in $100 \mathrm{ml}$ of TSB and processed for isolation of E. coli O157, non-O157 STEC and Salmonella.

\section{Fresh Produce Sample Preparation}

Each produce sample was weighed and suspended in $100 \mathrm{ml}$ Buffered Peptone Water (BPW). Each sample bag was manually massaged for $2 \mathrm{~min}$ and then incubated at $37^{\circ} \mathrm{C}$ for $2 \mathrm{~h}$ to aid in the recovery of injured cells (Pagadala et al., 2015). A $25 \mathrm{ml}$ aliquot from each bag from the previous step was transferred into $225 \mathrm{ml}$ of LEB and $50 \mathrm{ml}$ to $200 \mathrm{ml}$ of TSB. LEB and TSB enrichments were incubated following the same protocol as the soil sample enrichment bags. $4 \mathrm{ml}$ of the LEB and TSB enrichments were mixed with $1 \mathrm{ml}$ of $100 \%$ glycerol and frozen for future pathogen analysis (STEC, E. coli O157, Salmonella, generic E. coli, and L. monocytogenes) following the same protocols outlined below.

\section{Bacterial Enrichment and Isolation Non-0157 STEC Enrichment and Isolation}

For qualitative non-O157 STEC confirmation (Cooley et al., 2013), $1 \mathrm{ml}$ of the initial TSB pre-enrichment broth was transferred to $9 \mathrm{ml}$ of modified enterohemorrhagic E. coli (mEHEC) selective media (Biocontrol, Bellevue, WA, USA) tubes, which were incubated at $42^{\circ} \mathrm{C}$ for $12 \mathrm{~h}$ with agitation. $10 \mu \mathrm{l}$ were then streaked onto ChromSTEC $\left(\mathrm{CHROMagar}{ }^{\mathrm{TM}}\right.$, Paris, France), and plates were incubated at $37^{\circ} \mathrm{C}$ for $24 \mathrm{~h}$. From the primary plates, six presumptive non-O157 STEC colonies were selected and sub-streaked to secondary and tertiary plates. Presumptive positives were confirmed for the presence of $s t x 1$ (348 bp) and $s t x 2(584 \mathrm{bp})$ genes using a traditional polymerase chain reaction (PCR) assay (Paton and Paton, 1998).

\section{Listeria Monocytogenes Enrichment and Isolation}

The aforementioned LEB enrichment was subjected to immunomagnetic separation (IMS) to concentrate $L$. monocytogenes cells as previously described (Cooley et al., 2014). IMS was automated using the Dynal Bead Retriever (Invitrogen/Dynal, Carlsbad, CA) and the L. monocytogenes protocol established by the manufacturer. After carrying out IMS, a 30- $\mu$ l aliquot of washed IMS beads was plated onto Brilliance Listeria Agar (BLA; Oxoid, Hants, UK) supplemented with Brilliance Listeria Differential Supplement (Oxoid, Hants, UK) and Brilliance Listeria Selective Supplement (Oxoid, Harts, UK). A 100- $\mu$ l aliquot of washed IMS beads was added to $5 \mathrm{ml}$ of Fraser broth (BD, Sparks, MD). Both BLA plates and Fraser broth tubes were incubated at $37^{\circ} \mathrm{C}$ for $48 \mathrm{~h}$. Up to four presumptive L. monocytogenes colonies on the BLA plates were re-streaked to a secondary BLA plate, followed by a tertiary isolation. If the Fraser Broth turned black, one full $10-\mu l$ loop was added to BLA and streaked and isolated using the same protocol as the BLA plates. All presumptive L. monocytogenes colonies were streaked on TSA and confirmed by PCR assay, which screened for the hlyA gene (LM1: 5'CGGAGGTTCCGCAAAAGATG-3', LM2: 5'-CCTCCAGAGTGATCGATGTT-3') (Kawasaki et al., 2005).

\section{E. coli O157:H7 Enrichment and Isolation}

TSB enrichments were subjected to IMS to concentrate E. coli O157:H7 cells as previously described (Cooley et al., 2013). Washed IMS beads $(50 \mu \mathrm{l})$ were plated onto two selective and differential media; CT-SMAC (BBL ${ }^{\mathrm{TM}}$; Sorbitol MacConkey II Agar with Cefixime and Tellurite) and Rainbow Agar O157 (Biolog, Hayward, CA) containing novobiocin $(20 \mathrm{mg} / \mathrm{L}$; SigmaAldrich) and potassium tellurite $(0.8 \mathrm{mg} / \mathrm{L}$; Invitrogen/Dynal $)$ (MP Biomedicals, Solon, OH, USA). Plates were incubated at $37^{\circ} \mathrm{C}$ for $24 \mathrm{~h}$. Up to two presumptive E. coli $\mathrm{O} 157: \mathrm{H} 7$ colonies for each plate (four presumptive colonies per sample) were selected by colony color and morphology and streaked for isolation onto the opposite plate (i.e., CT-SMAC onto Rainbow; Rainbow onto CT-SMAC) and carried out once more for a tertiary isolation (Cooley et al., 2013). Presumptive E. coli O157:H7 colonies were confirmed by PCR assay, which screened for the eaeA gene (VS8: 5'-GGCGGATTAGACTTCGGCTA3', VS9: 5'-CGTTTTGGCACTATTTGCCC-3') (Kawasaki et al., 2005).

\section{Salmonella spp. Enrichment and Isolation}

The Food and Drug Administration's Bacteriological Analytical Manual (BAM) method was modified to use TSB for simultaneous pre-enrichment of both E. coli and Salmonella as previously described (Food and Drug Administration, 2018; Pires et al., 2019). Modifications made to the FDA-BAM method are briefly described as follows: $1 \mathrm{ml}$ from the initial TSB enrichment was transferred into $9 \mathrm{ml}$ BPW (Hardy Diagnostics, Santa Maria, CA) and incubated at $37^{\circ} \mathrm{C}$ for $24 \mathrm{~h}$. Then, $1 \mathrm{ml}$ and $0.1 \mathrm{ml}$ aliquots of non-selective BPW were transferred to $10 \mathrm{ml}$ of Tetrathionate (TT) broth and Rappaport-Vassiliadis (RV) broth (BD, Sparks, MD), respectively. Both TT and RV broth were incubated at $42^{\circ} \mathrm{C}$ for $24 \mathrm{~h}$. TT broth and RV selective enrichments were plated in parallel on Xylose lysine desoxycholate Tergatol-4 (XLT4) agar supplemented with XLT4 supplement (BD Difco, Le Pont de Claix, France) using a 10- $\mu \mathrm{l}$ inoculation loop and incubated at $37^{\circ} \mathrm{C}$ for $24 \mathrm{~h}$. Up to two presumptive colonies were selected from each XLT4 plate and re-streaked for isolation twice. Presumptive Salmonella spp. colonies were transferred to TSA and confirmed using a polymerase chain reaction (PCR) assay that $\operatorname{detects} i n v A$, a gene specific to Salmonella enterica (Kawasaki et al., 2005).

\section{Generic E. coli Enrichment, Enumeration, and Isolation}

Soil and produce samples were tested for the presence and concentration of generic E. coli (Most Probable Number, MPN/g) as previously described (Atwill et al., 2015; Patterson et al., 2018). Each TSB bag (prior to enrichment) was used as a source for 
TSB reservoirs (E and K Scientific, Santa Clara, CA, USA), which were serially diluted and used for enumeration of generic $E$. coli. Briefly, the first column of a 48-well reservoir was filled with $5 \mathrm{ml}$ of the sample, followed by five columns filled with $4.5 \mathrm{ml}$ TSB. Serial dilutions were carried out up to $10^{-6}$ in four replications per sample (Atwill et al., 2015; Patterson et al., 2018). Samples were incubated at $25^{\circ} \mathrm{C}$ for $2 \mathrm{~h}$ followed by $42^{\circ} \mathrm{C}$ for $8 \mathrm{~h}$ with $100 \mathrm{rpm}$ shaking. Samples were then held at $6^{\circ} \mathrm{C}$ with no shaking. $4 \mu \mathrm{l}$ from each dilution in the TSB reservoir was streaked onto CHROMagar ECC (CHROMagar, Paris, France) followed by incubation for $24 \mathrm{~h}$ at $37^{\circ} \mathrm{C}$ (Atwill et al., 2015). MPN series cell densities were calculated based on dilution to extinction using an MPN Calculator (Curiale, 2004). After recording each potentially positive sample, up to four presumptive generic E. coli colonies per positive sample were selected for and re-streaked onto secondary and tertiary CHROMagar ECC plates. After their respective incubations, the pure isolates were confirmed as generic E.coli using a PCR assay targeting the universal stress protein (uspA) gene (884 bp, 5'CCGATACGCTGCCAATCAGT 3', 5' ACGCAGACCGTAGGCCAGAT $3^{\prime}$ ), as described previously (Chen and Griffiths, 1998). For each positive sample, up to four isolates were banked in a $15 \%$ glycerol and $85 \%$ TSB solution and stored for potential subsequent analyses in a $-80^{\circ} \mathrm{C}$ freezer.

\section{Statistical Analysis}

Descriptive analysis was done by computing un-adjusted apparent prevalence for each pathogen in manure, soil, water, and produce samples and adjusted apparent prevalence in soil samples. Prevalence is defined as the percentage of positive samples tested for the four tested and culturable bacterial foodborne pathogens out of the total samples collected for each tested matrix. Such prevalence computations were conducted overall but also stratified by year, over the sampling timeline, between states, between manure types, and by generic E. coli populations. Un-adjusted apparent prevalence was calculated by dividing the total number of positive samples by the total number of tested samples for said pathogen in a given setting (i.e., by farm, by state, etc.). For each un-adjusted apparent prevalence value, $95 \%$ confidence intervals were computed using the following formula for percentage confidence intervals (Hogg et al., 2015):

$$
p \pm 1.96 * \sqrt{\frac{p *(1-p)}{N}}
$$

where $p$ is the un-adjusted apparent prevalence and $N$ is the number of tested samples. As sampling was clustered in space, we computed prevalence values adjusted for clustering. For this, we conducted mixed-effect logistic regression with the farm as random effects in $\mathrm{R}$ studio using the package lme4 (Bates et al., 2015; R Core Team, 2020). For this, year, state, manure type, and generic E. coli levels were used as categorical fixed effects. Each fixed effect was studied independently from the others in univariate models as the goal was not to identify significant risk factors but adjust prevalence for clustering within each of the categories of these variables. The coefficients from these models were then used to estimate the adjusted prevalence within each level of the fixed effect included, using the coefficient standard errors to compute $95 \%$ confidence intervals. Prevalence values and confidence intervals were plotted in excel. Correlation between the presence of the different pairs of pathogenic bacteria in both manure and soil sample was graphed and computed using the corrgram package in $\mathrm{R}$ (Wright, 2018) using the Pearson correlation. As these data are binary, a positive correlation reflects that two pathogens are more likely found together, with a value of one meaning all samples would have the two pathogens. A negative correlation would imply that the two pathogens are more likely to be found without the other, with a value of -1 meaning that the two pathogens never are present at the same time in a single sample.

\section{RESULTS}

\section{Study Population}

Over the 21 months of the study, 19 farms participated; nine farms are located in California, five in Maine, four in Minnesota, and one in Maryland. Of these, one Maine farm participated only in 2017 and one farm each in California, Maine, and Minnesota participated only in 2018, with the remaining 15 farms participating in both years. The number of soil samples collected each sampling day between day 30 and 180 varied between four and 27 depending on the farm and the number of plots per farm. All farms were USDA-NOP certified-organic and produced fresh produce, 10 farms produce fruit and nut trees, 12 produce herbs or hops, and three animal feed. All farms applied untreated manure to the produce fields, in addition to: compost (17), grazing (2), green waste (3), and other BSAAOs (11, including fish meal, bone meal, feather meal). Manure sources included: cattle (9), poultry (8), horse (7), small ruminants (4), and swine (1), while 13 farms used multiple sources. The origin of manure was on-site (12), local non-commercial (5) and commercial (4). Agricultural water sources included well (15), surface (i.e., pound, creek) (7) and municipal (3). The majority of the farms used drip irrigation (17) follow by overhead (6), sprinkler (6) and farrow (1). The soil type also varied, including sand-loam (11), loam (3), silt-loam (2), clay-loam (1), silt-clay (1) and silt-clay-loam (1). In 2017, of the 16 farms that participated in the study, all conducted sampling until day 120 . However, one farm missed sampling on day 150 due to weather conditions, but went on to collect data on day 180. Two farms stopped at day 150 due to the end of growing season and did not collect any data for day 180 . Thus, only 13 farms had samples for every collection day that year. Two other farms had incomplete data collections during the study, one at day 30 (six instead of eight samples) and the other at day 60 (four instead of 16 samples). For 2018, of the 18 farms participating, three stopped sampling at day 120, not collecting data on days 150 and 180, and another three stopped collecting at day 150 , with no data for day 180 . Thus, only 12 farms had samples for all sampling days that year. One farm had some missing data on day 30 (18 instead of 27 samples). Days 0A and $\mathrm{OB}$ often did not have the same number of samples as the other sampling days of the study. This was the case in five farms in 2017 and six farms in 2018. This led to the sample databased 
not being fully balanced as planned in the study design. Other type of samples (manure, produce, and water) followed a similar collection frame.

\section{Produce Samples}

Of 527 produce samples, only two $(0.4 \%)$ were positive for $L$. monocytogenes, and none of the other three tested pathogens were positive. These two samples were independent from each other in terms of year and location. Both were leafy greens samples which were also positive for generic E. coli. One was a Swiss Chard "Bright Lights" sample taken on day 90 with the other being a parsley sample taken on day 120 . The first came from a field where no manure was used, whereas the second came from a field which used cattle manure. Of 525 produce samples, 118 (22.5\%) were positive for generic E. coli. The remaining two samples were missing generic $E$. coli results (Table 1).

\section{Untreated Manure and Compost Samples}

Of the 19 farms sampled, seven farms provided compost samples and 18 provided untreated manure samples. Of the seven farms where compost was collected, six actually applied it in studied fields and four of these used commercial compost. Of 233 untreated manure and compost samples, a total of 42 (18.0\%) samples were positive for at least one of the tested foodborne pathogens. This represented 35 of 176 untreated manure samples (19.9\%) and 7 of 57 compost samples (12.3\%, five of 16 in-house compost and two of 41 commercial compost) (Table 2). These were distributed in 12 of the 19 farms (63.2\%) under study, 20 samples in nine farms for 2017 and 22 samples in six farms for 2018. Ten of the positive samples were concentrated from one farm, and another farm had eight positive samples (Table 3 ). Of the 233 samples, 21 samples (9.0\%) were positive for nonO157 STEC, 17 (7.3\%) were positive for Salmonella spp., nine (3.9\%) were positive for L. monocytogenes and three (1.3\%) were positive for E. coli O157. Non-O157 STEC and L. monocytogenes were primarily found in ruminant manure whereas Salmonella spp. was found in ruminant and poultry manure. Mixed manure samples that were positive were nearly all a mixture of ruminant and poultry manure, with three also containing some horse manure. Horse manure samples only showed one positive for L. monocytogenes and none of the other pathogenic bacteria (Table 2). Based on the standard rule of thumb for Pearson' correlation coefficient (Mukaka, 2012; Schober et al., 2018) there was a weak to negligible correlation between pathogen samples themselves, with correlation values ranging between -0.02 and 0.26 . The two highest values were between E. coli $\mathrm{O} 157$ and Salmonella spp. with a value of 0.26 , and between Salmonella spp. and L. monocytogenes with a value of 0.20 . Other correlation values were between -0.02 and 0.10 . Of 42 samples positive for at least one pathogen, only seven were positive for multiple pathogens. Of these seven samples, one was positive for O157 STEC, non-O157 STEC, and Salmonella spp. combined, one was positive for E. coli O157 and Salmonella spp., two were positive for non-O157 STEC and Salmonella spp., and three were positive for Salmonella and L. monocytogenes. Overall, we can observe some moderate correlation between Salmonella spp. and L. monocytogenes prevalence and between O157 STEC and Salmonella spp. prevalence.

\section{Soil Samples}

Of 2,461 soil samples, 318 samples (12.9\%) were positive for at least one of the pathogens in the study. Of these, $190(7.7 \%)$ were positive for non-O157 STEC, $122(5.0 \%)$ were positive for $L$. monocytogenes, 26 (1.1\%) were positive for Salmonella spp., and one $(0.04 \%)$ was positive for E. coli O157. Out of 2,405 samples, 1,445 samples (60.1\%) were positive for generic E. coli. Even more so than with manure samples, there was little correlation, with values for correlation ranging between 0.01 and 0.03 , except between Salmonella spp. and L. monocytogenes which had a value of 0.10 between the different pathogens, with 14 samples being positive for both non-O157 STEC and L. monocytogenes, and another seven being positive for both Salmonella and L. monocytogenes. For Salmonella, non-O157 STEC, and $L$. monocytogenes, prevalence was adjusted for clustering within farm, state, and year with the results presented in Table 4 . The adjusted apparent prevalence numbers are lower than the unadjusted apparent prevalence, suggesting strong farm clustering. For non-O157 STEC, adjusted prevalence decreased by $27 \%$, for Salmonella spp. by $73 \%$, and for L. monocytogenes by $32 \%$ compared to the un-adjusted apparent prevalence. To add to spatial clustering, data was also unevenly distributed between years as can be seen when comparing the prevalence between both years of the study (Table 4). For non-O157 STEC, 93.9\% of (171/190) positive samples occurred in 2017. Moreover, 61 of these came from a single farm (53 in 2017 and eight in 2018), with 25 coming from another farm (all in 2017), accounting for the spatial clustering. Interestingly, the farm with 61 positive samples had three out of eight positive manure samples in 2017 compared to zero out of eight in 2018. Similarly, the farm with 25 positive samples in 2017 had two out of four manure samples positive for non-O157 STEC in 2018 but zero out of 20 in 2017 (Table 2). For Salmonella spp., 96.2\% (25/26) of positive samples happened in 2018, with 11 coming from one farm and seven from another, demonstrating extreme space-time clustering of our data. L. monocytogenes data was more evenly distributed with 77 positives in 2017 and 45 in 2018. Moderate clustering was observed with four farms having zero positives and six farms containing more than 10 positive samples each, for a total of 74 positive samples (Table 2).

The single E. coli O157 STEC positive soil sample was collected in California on day 90, from a plot on which lettuce was being grown using mixed duck-horse manure. Given the fact that only one sample was positive, no further analysis was conducted. For the other pathogens we looked at the trends of prevalence over time as well as the difference between state and manure types. We also looked at the association of generic $E$. coli on the presence of pathogen. Overall, the models didn't show any strong evidence that prevalence for any pathogen varied by state (Table 4). There was some moderate evidence of association with the manure type applied and detection in the soil. Adjusted values showed evidence that soil samples where cattle manure was used had a higher adjusted prevalence of non-O157 STEC compared to samples where any other type of manure was used, with the 
TABLE 1 | Overall generic E. coli most probable number (MPN) and prevalence of produce samples collected in this longitudinal study on certified organic farms.

\begin{tabular}{|c|c|c|c|c|c|}
\hline & $\begin{array}{c}\text { Fruit }^{*} \\
(n=211)\end{array}$ & $\begin{array}{l}\text { Ground fruit }{ }^{+} \\
\quad(n=57)\end{array}$ & $\begin{array}{l}\text { Leafy green }{ }^{\#} \\
\qquad(n=200)\end{array}$ & $\begin{array}{l}\text { Root vegetables }{ }^{\&} \\
(n=57)\end{array}$ & $\begin{array}{l}\text { Overall } \\
(n=525)\end{array}$ \\
\hline $\begin{array}{l}\text { Positive to } \\
\text { generic E. coli (\%) }\end{array}$ & $19(9.0)$ & $9(15.8)$ & 67 (33.5) & $23(40.4)$ & $118(22.5)$ \\
\hline \multicolumn{6}{|l|}{$\log _{10}(M P N+1)$} \\
\hline Mean (SD) & $0.086(0.366)$ & $0.068(0.206)$ & $0.374(0.861)$ & $0.454(0.904)$ & $0.234(0.672)$ \\
\hline Median [min, max] & $0[0,2.50]$ & $0[0,1.29]$ & $0[0,4.85]$ & $0[0,4.50]$ & $0[0,4.85]$ \\
\hline
\end{tabular}

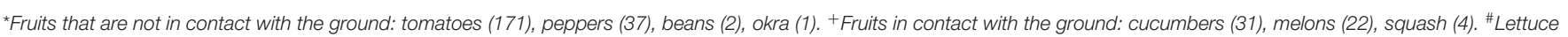

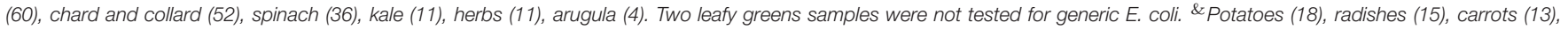
beets and turnips (13).

TABLE 2 | Distribution of positive samples for four foodborne pathogens in manure and compost samples by type or age of manure and type of pathogen collected in this longitudinal study on certified organic farms.

\begin{tabular}{|c|c|c|c|c|c|c|}
\hline $\begin{array}{l}\text { Manure type } \\
\text { and age }\end{array}$ & Total samples & $\begin{array}{c}\text { Samples positive } \\
(\%)\end{array}$ & $\begin{array}{c}\text { E. coli 0157:H7 } \\
(\%)\end{array}$ & $\begin{array}{c}\text { Non-0157 STEC } \\
(\%)\end{array}$ & $\begin{array}{c}\text { Salmonella spp. } \\
(\%)\end{array}$ & $\begin{array}{c}\text { Listeria } \\
\text { monocytogenes } \\
(\%)\end{array}$ \\
\hline Poultry* & 55 & $9(16.4)$ & $1(1.8)$ & 2 (3.6) & $6(10.9)$ & - \\
\hline Cattle* & 53 & $13(24.5)$ & 0 & $5(9.4)$ & $5(9.4)$ & 7 (13.2) \\
\hline Horse $^{\star}$ & 49 & $1(2.0)$ & 0 & 0 & 0 & $1(2.0)$ \\
\hline Small ruminants ${ }^{*}$ & 38 & 7 (18.4) & 0 & 7 (18.4) & 0 & 0 \\
\hline Swine* & 3 & 1 (33.3) & 0 & 1 (33.3) & 0 & 0 \\
\hline Mixed $^{\star+}$ & 35 & $11(31.4)$ & $2(5.7)$ & $6(17.1)$ & $6(17.1)$ & $1(2.9)$ \\
\hline TOTAL & 233 & $42(18.0)$ & $3(1.3)$ & $21(9.0)$ & $17(7.3)$ & $9(3.9)$ \\
\hline 0-2 months ${ }^{\#}$ & 62 & $18(29.0)$ & $1(1.6)$ & $10(16.1)$ & $8(12.9)$ & $1(1.6)$ \\
\hline 2-6 months ${ }^{\#}$ & 39 & 4 (10.3) & - & $2(5.1)$ & $2(5.1)$ & $2(5.1)$ \\
\hline 6-12 months $\#$ & 47 & 15 (31.9) & $1(2.1)$ & 5 (10.6) & 7 (14.9) & $6(12.8)$ \\
\hline >12 months ${ }^{\#}$ & 44 & $3(6.8)$ & $1(2.3)$ & $2(4.5)$ & 0 & 0 \\
\hline $\begin{array}{l}\text { Commercial } \\
\text { compost }\end{array}$ & 41 & $2(4.9)$ & 0 & $2(4.9)$ & 0 & 0 \\
\hline
\end{tabular}

*Animal source of manure and compost. ${ }^{+}$Mixed type contains manure and compost from multiple animal sources. ${ }^{*}$ Age of raw and untreated manure.

value for soil samples with other manure types being mostly below the lower bound of the $95 \%$ confidence interval for soil samples with cattle manure (Table 5). This was the case for all types except for poultry manure, which was just above that lower bound, still showing borderline evidence that samples with cattle manure were more likely to be positive than those with poultry manure. This is in line with the un-adjusted apparent prevalence, where samples with cattle manure also had higher prevalence of non-O157 STEC. Similarly, we found evidence that samples in which poultry, cattle, horse, or mixed manure was applied had lower adjusted Salmonella spp. prevalence compared to samples in which small ruminant manure was applied. Soil samples with cattle manure also showed moderate evidence of having lower Salmonella spp. prevalence compared to samples with poultry manure. Though samples with horse or mixed manure had lower adjusted Salmonella spp. prevalence compared to samples with poultry manure, this difference was not significant. Finally, for L. monocytogenes, we saw evidence that samples where cattle manure was used had higher prevalence compared to samples where poultry, horse, and mixed manure was used. Samples where small ruminant manure was applied showed a similar prevalence, but with a much wider confidence interval due to the smaller sample size of this category. The other three categories all had very similar adjusted prevalence to one another (Table 5).

For non-O157 STEC there was a significant spike on the day of manure application (day 0B), before dropping back to pre-application levels (day 60 and 90). However, from day 120 forward, there was again significant increase in prevalence compared to manure pre-application levels (Figure 1). When looking at the association with generic $E$. coli, there was a significant association with a visible trend. From values of one and above of $\log$ (mpn/g of dry soil), almost all categories were significantly above samples with no generic E. coli (Figure 2).

For Salmonella spp., the results by sampling day were hard to interpret due to the small sample size of positive samples with many days having zero positive samples leading to model convergence issues. However, it seems that though day 0B (postmanure application) did not significantly differ from day $0 \mathrm{~A}$ (pre-manure application), there was enough evidence to suggest that from day 30 onwards, prevalence was significantly lower 
TABLE 3 | Total samples collected and positive samples of three foodborne pathogens from soil and manure by farm and sample type collected in this longitudinal study on certified organic farms.

\begin{tabular}{|c|c|c|c|c|c|c|c|c|c|}
\hline & \multicolumn{4}{|c|}{ Soil samples } & \multicolumn{4}{|c|}{ Manure samples } & \multirow{2}{*}{$\begin{array}{c}\text { Produce } \\
\text { samples } \\
\text { Sample } \\
\text { number }\end{array}$} \\
\hline & $\begin{array}{l}\text { Sample } \\
\text { number }\end{array}$ & $\begin{array}{l}\text { non-0157 } \\
\text { STEC (\%) }\end{array}$ & $\begin{array}{c}\text { Salmonella } \\
\text { spp. (\%) }\end{array}$ & $\begin{array}{c}\text { Listeria } \\
\text { monocytogenes } \\
(\%)\end{array}$ & $\begin{array}{l}\text { Sample } \\
\text { number }\end{array}$ & $\begin{array}{c}\text { non-0157 STEC } \\
(\%)\end{array}$ & $\begin{array}{l}\text { Salmonella } \\
\text { spp. (\%) }\end{array}$ & $\begin{array}{c}\text { Listeria } \\
\text { monocytogenes } \\
\text { (\%) }\end{array}$ & \\
\hline CA1 & 126 & $9(7.1)$ & 0 & $8(6.3)$ & 16 & 0 & 2 (12.5) & 0 & 18 \\
\hline CA2 & 136 & 24 (17.6) & 0 & 0 & 32 & 2 (6.3) & 1 (3.1) & 0 & 33 \\
\hline CA3 & 56 & $5(8.9)$ & $1(1.8)$ & 0 & 7 & $3(42.9)$ & 0 & 0 & 15 \\
\hline CA4 & 92 & $4(4.3)$ & $1(1.1)$ & 7 (7.6) & 6 & 0 & 0 & 0 & 19 \\
\hline CA5 & 128 & $18(14.1)$ & $1(0.8)$ & 17 (13.3) & 10 & 0 & 0 & 0 & 26 \\
\hline CA6 & 128 & $7(5.5)$ & $7(5.5)$ & 11 (8.6) & 10 & 0 & 0 & 0 & 18 \\
\hline CA7 & 128 & $6(4.7)$ & 0 & 0 & 22 & 0 & 0 & 0 & 40 \\
\hline CA8 & 128 & $11(8.6)$ & 0 & $6(4.7)$ & 13 & 0 & 0 & 0 & 29 \\
\hline CA9 & 142 & $2(1.4)$ & 0 & 0 & 28 & 5 (17.9) & 0 & 0 & 27 \\
\hline MD1 & 196 & $10(5.1)$ & 0 & $8(4.1)$ & 9 & $1(11.1)$ & 0 & 0 & 32 \\
\hline ME1 & 120 & $3(2.5)$ & $4(3.3)$ & $7(5.8)$ & 10 & 0 & 0 & 0 & 40 \\
\hline ME2 & 32 & $6(18.8)$ & 0 & 5 (15.6) & 5 & 0 & 1 (20.0) & 0 & 4 \\
\hline ME3 & 172 & $5(2.9)$ & $1(0.6)$ & $13(7.6)$ & 18 & $2(11.1)$ & 7 (38.9) & $4(22.2)$ & 40 \\
\hline ME4 & 64 & $3(4.7)$ & 0 & 10 (15.6) & 10 & $3(30.0)$ & 0 & $1(10.0)$ & 12 \\
\hline ME5 & 112 & $1(0.9)$ & 0 & 0 & 2 & 0 & 0 & 0 & 50 \\
\hline MN1 & 164 & 3 (1.8) & 0 & $12(7.3)$ & 5 & $2(40.0)$ & $2(40.0)$ & $2(40.0)$ & 21 \\
\hline MN2 & 171 & $11(6.4)$ & 0 & $11(6.4)$ & 10 & 0 & 0 & $1(10.0)$ & 32 \\
\hline MN3 & 342 & $61(17.8)$ & $11(3.2)$ & $8(2.3)$ & 16 & 3 (18.8) & $4(25.0)$ & $1(6.3)$ & 55 \\
\hline MN4 & 25 & 0 & 0 & 0 & 4 & 0 & 0 & 0 & 16 \\
\hline
\end{tabular}

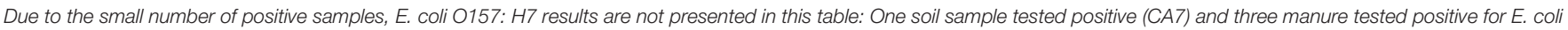
0157: H7(CA2, ME1 and ME3). Only two produce samples tested positive for L. monocytogenes (ME4, ME5) and none for the other pathogens.

compared to both day $0 \mathrm{~A}$ and $0 \mathrm{~B}$ (Figure 3). Similarly, for nonO157 STEC, there was a significant association with generic E. coli with increasing values of generic E. coli associated with increasing prevalence in Salmonella spp (Figure 4).

Finally, for L. monocytogenes, there was also significant evidence of the effect of time, with a spike (though not statistically significant) on day $0 \mathrm{~B}$, when manure was applied, followed by a significant drop up to day 60 , when prevalence stabilized (Figure 5). Here the association with generic E. coli was harder to evaluate, with only samples with $\log (\mathrm{MPN} / \mathrm{g}$ dry soil) values of four to five being significantly higher from samples with no generic E. coli. Other levels of generic E. coli were not significantly different from negative generic E. coli samples (Figure 6).

In 2017, five farms had both manure and soil samples positive for non-O157 STEC, four of which still had positive soil samples by days 120 to 180 . These included the previously mentioned farm with 53 positive samples in 2017, 35 of which were on day 120 or later. In 2018, two farms had both manure and soil samples positive for non-O157 STEC, with no positive soil samples after day 90. For Salmonella spp., only two farms had both soil and manure samples positive in 2018 and none in 2017. No positive soil samples were found after day 30. Finally, for $L$. monocytogenes, four farms in 2017 and two in 2018 had positive samples in both manure and soil samples. Two of these farms had positive soil samples after day 120 in 2017, but none in 2018 .

\section{Water Samples}

Overall, 39 water samples were collected: 24 from well water, seven from surface water, five from the irrigation line, and two from municipal water. Of these $20.5 \%$ (8) were positive for generic $E$. coli, five of which came from surface water samples and one in each of the three other types of water. The eight positive samples had $\log (\mathrm{CFU})$ values that ranged from 0.77 to 2.31 .

\section{DISCUSSION}

\section{Produce Contamination}

Results from this study indicate that on these farms and in the years and time periods sampled, the prevalence of foodborne pathogens on organic crops was low, even when untreated manure was used to amend the soil. < half of $1 \%$ of the produce samples tested positive for human pathogens, and of the two produce samples that tested positive for L. monocytogenes, one was from a field where manure was not applied. This finding indicates that manure amendment was not the sole source of pathogens transfer to organic produce in these farms, where an appropriate time intervals were waited between manure application and harvest (Nightingale et al., 2004; Ingham et al., 2005; Szymczak et al., 2014). On other hand, recovery 


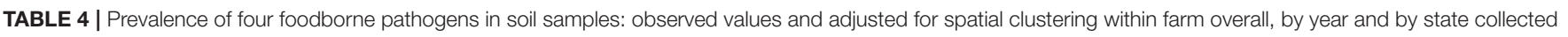
in this longitudinal study on certified organic farms.

\begin{tabular}{|c|c|c|c|c|c|c|c|}
\hline Pathogen & Category & $\begin{array}{c}\text { Total } \\
\text { samples }\end{array}$ & $\begin{array}{l}\text { Positive } \\
\text { samples }\end{array}$ & $\begin{array}{c}\text { Un-adjusted apparent } \\
\text { prevalence }(\%)\end{array}$ & $95 \% \mathrm{Cl}$ & $\begin{array}{l}\text { Adjusted apparent } \\
\text { prevalence }(\%)\end{array}$ & $95 \% \mathrm{Cl}$ \\
\hline \multirow[t]{7}{*}{ E. coli O157:H7 } & Total & 2461 & 1 & 0.04 & 0.0 to 0.1 & NA & NA \\
\hline & 2017 & 1133 & 0 & 0 & NA & NA & NA \\
\hline & 2018 & 1328 & 1 & 0.08 & 0.0 to 0.2 & NA & NA \\
\hline & California & 1065 & 1 & 0.09 & 0.0 to 0.8 & NA & NA \\
\hline & Maryland & 196 & 0 & 0.0 & NA & NA & NA \\
\hline & Maine & 500 & 0 & 0.0 & NA & NA & NA \\
\hline & Minnesota & 700 & 0 & 0.0 & NA & NA & NA \\
\hline \multirow[t]{7}{*}{ Non-O157 STEC } & Total & 2461 & 190 & 7.7 & 6.7 to 8.8 & 5.6 & 3.8 to 8.1 \\
\hline & 2017 & 1133 & 171 & 15.1 & 13.0 to 17.2 & 11.9 & 8.6 to 16.3 \\
\hline & 2018 & 1328 & 19 & 1.4 & 0.8 to 2.1 & 0.7 & 0.7 to 1.7 \\
\hline & California & 1065 & 87 & 8.2 & 6.5 to 9.8 & 6.9 & 4.1 to 11.2 \\
\hline & Maryland & 196 & 10 & 5.1 & 2.0 to 8.2 & 4.9 & 1.0 to 21.2 \\
\hline & Maine & 500 & 18 & 3.6 & 2.0 to 5.2 & 3.7 & 1.5 to 9.2 \\
\hline & Minnesota & 700 & 75 & 10.7 & 8.4 to 13.0 & 5.6 & 2.1 to 14.0 \\
\hline \multirow[t]{7}{*}{ Salmonella spp. } & Total & 2461 & 26 & 1.1 & 0.8 to 1.3 & 0.3 & 0.1 to 1.2 \\
\hline & 2017 & 1133 & 1 & 0.09 & 0.0 to 0.3 & 0.02 & 0.0 to 0.2 \\
\hline & 2018 & 1328 & 25 & 1.9 & 1.2 to 2.6 & 0.4 & 0.1 to 3.2 \\
\hline & California & 1065 & 10 & 0.9 & 0.4 to 1.5 & 0.3 & 0.1 to 1.3 \\
\hline & Maryland & 196 & 0 & 0.0 & NA & NA & NA \\
\hline & Maine & 500 & 5 & 1.0 & 0.1 to 1.9 & 0.4 & 0.0 to 4.2 \\
\hline & Minnesota & 700 & 11 & 1.6 & 0.7 to 2.5 & 0.3 & 0.0 to 4.3 \\
\hline \multirow[t]{7}{*}{ Listeria monocytogenes } & Total & 2461 & 122 & 5.0 & 4.3 to 5.6 & 3.4 & 1.8 to 6.4 \\
\hline & 2017 & 1133 & 77 & 6.8 & 5.3 to 8.3 & 4.5 & 2.5 to 8.2 \\
\hline & 2018 & 1328 & 45 & 3.4 & 2.4 to 4.4 & 2.7 & 1.8 to 3.9 \\
\hline & California & 1065 & 48 & 4.5 & 3.3 to 5.8 & 2.4 & 1.0 to 5.9 \\
\hline & Maryland & 196 & 8 & 4.1 & 1.3 to 6.9 & 3.9 & 0.3 to 33.3 \\
\hline & Maine & 500 & 35 & 7.0 & 4.8 to 9.2 & 6.1 & 1.6 to 20.8 \\
\hline & Minnesota & 700 & 31 & 4.4 & 2.9 to 6.0 & 3.6 & 0.8 to 14.5 \\
\hline
\end{tabular}

of pathogen(s) on produce harvested from a manured field after an appropriate wait period could implicate manure as a potential source, particularly if isolate source tracing analyses were available.

In this study, a variety of produce items, including root vegetables, leafy greens, and fruits, were sampled as opposed to other studies limited to one type fresh produce (Marine et al., 2015; Pagadala et al., 2015; Park et al., 2015). Type of produce and production factors, such as proximity of harvestable portions to the soil and irrigation type and quality, are major aspects to consider when deciding on use of untreated BSAAOs for produce fields. The pathogen, L. monocytogenes, found on produce samples is a naturally occurring pathogen in soil, water, and manure, thus it can originate from non-manure sources (Zhu et al., 2017). The findings in this study, that there is a relatively infrequent, i.e., low, prevalence of produce contamination when untreated manure is applied in accordance with the NOP 90-120 day wait times for organic produce fields, are in agreement with previous findings in small to mediumscale fresh produce farms, where neither Salmonella spp. nor
non-O157 STEC were isolated from tomatoes (Pagadala et al., 2015).

In addition to testing for pathogens, we also tested for generic E. coli. While most E. coli strains are non-pathogenic, testing is less costly than pathogen-specific tests, thus E. coli is frequently used as an indicator of fecal contamination in produce (Ingham et al., 2004, 2005; Pan et al., 2015; Denis et al., 2016; Patterson et al., 2018). In experimental field trials, where untreated manure was used, the presence of generic E. coli on produce was attributed to use of noncomposted manure in Wisconsin vegetable production (Ingham et al., 2005). Although, human pathogens such as Listeria monocytogenes and E. coli O157:H7 can occur in manure, the mere presence of generic $E$. coli in soil, produce, or water samples only indicates the presence of fecal contamination which can include $E$. coli on the produce. The actual presence of pathogens requires specific, costly, time-consuming testing (Uyttendaele et al., 2014; Pan et al., 2015). A major concern with finding fecal contamination on produce is that such contamination cannot be completely removed by washing, due 
TABLE 5 | Prevalence of four foodborne pathogens in in soil samples: observed values and adjusted for spatial clustering within farm by source of manure used on the soil collected in this longitudinal study in certified organic farms.

\begin{tabular}{|c|c|c|c|c|c|c|c|}
\hline Pathogen & Category & $\begin{array}{c}\text { Total } \\
\text { samples }\end{array}$ & $\begin{array}{l}\text { Positive } \\
\text { samples }\end{array}$ & $\begin{array}{c}\text { Un-adjusted } \\
\text { apparent } \\
\text { prevalence } \\
(\%)\end{array}$ & $95 \% \mathrm{Cl}$ & $\begin{array}{c}\text { Adjusted } \\
\text { apparent } \\
\text { prevalence } \\
(\%)\end{array}$ & $95 \% \mathrm{Cl}$ \\
\hline \multirow[t]{3}{*}{ Non-O157 STEC } & Poultry & 582 & 45 & 7.7 & 5.6 to 9.9 & 6.7 & 3.7 to 11.9 \\
\hline & Cattle & 567 & 70 & 12.3 & 9.6 to 15.1 & 9.9 & 6.2 to 15.5 \\
\hline & Horse & 486 & 26 & 5.3 & 3.3 to 7.4 & 3.9 & 1.4 to 10.3 \\
\hline \multirow[t]{5}{*}{ Salmonella spp. } & Poultry & 582 & 12 & 2.1 & 0.9 to 3.2 & 0.9 & 0.3 to 2.7 \\
\hline & Cattle & 567 & 4 & 0.7 & 0.0 to 1.4 & 0.3 & 0.1 to 1.0 \\
\hline & Horse & 486 & 1 & 0.2 & 0.0 to 0.6 & 0.1 & 0.0 to 2.2 \\
\hline & Small ruminant & 136 & 7 & 5.1 & 1.4 to 8.9 & 3.9 & 0.4 to 28.4 \\
\hline & Mixed & 639 & 2 & 0.3 & 0.0 to 0.7 & 0.3 & 0.0 to 2.2 \\
\hline & Small ruminant & 136 & 11 & 8.1 & 3.5 to 12.7 & 7.0 & 1.1 to 34.1 \\
\hline & Mixed & 639 & 18 & 2.8 & 1.5 to 4.1 & 2.9 & 0.9 to 8.8 \\
\hline
\end{tabular}

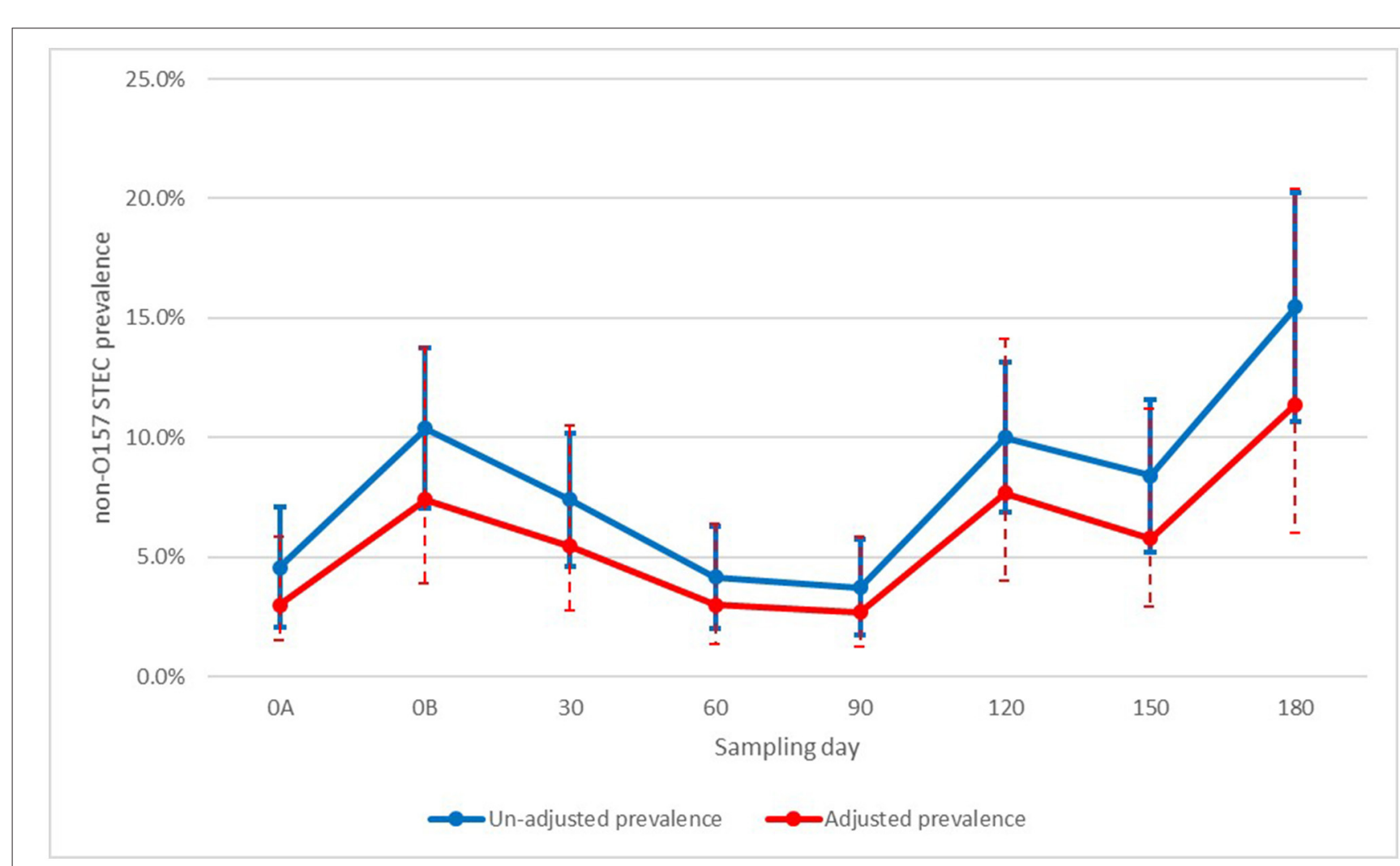

FIGURE 1 | Un-adjusted and adjusted apparent prevalence of non-O157 STEC in soil by sampling day with 95\% confidence intervals collected in a longitudinal study in certified organic farms.

to the formation of biofilms and the difficulty of having the wash water penetrate the produce surface. Studies comparing the prevalence of generic $E$. coli in organic vs. conventional produce are rare, but have not indicated a difference between organic and conventional produce (Pagadala et al., 2015; Kuan et al., 2017). 


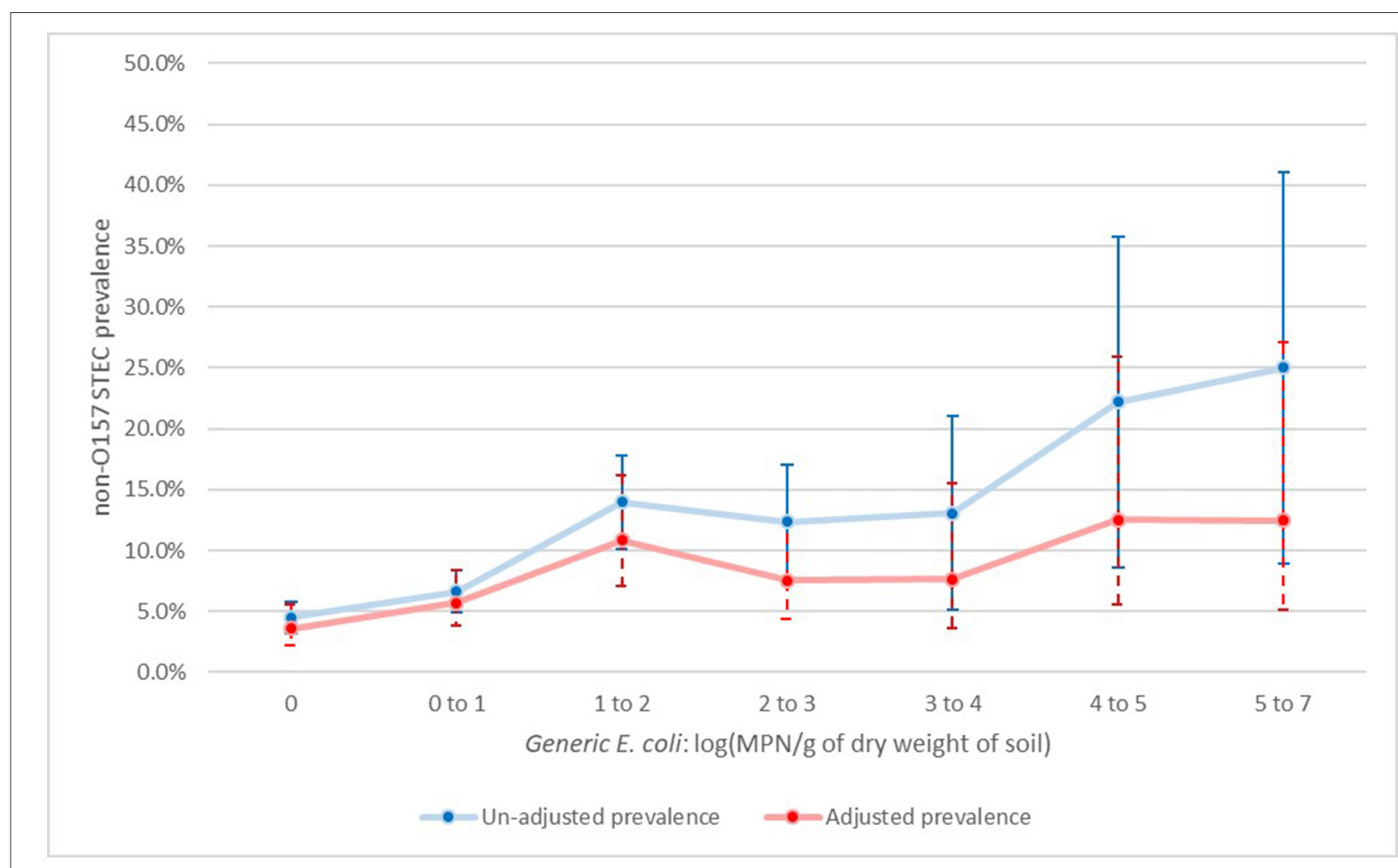

FIGURE 2 | Un-adjusted and adjusted apparent prevalence of non-O157 STEC in soil by levels of generic E.coli log(MPN/g of dry soil) with 95\% confidence intervals collected in a longitudinal study in certified organic farms.

In general, researchers have found a wide range of $E$. coli prevalence in fresh produce. For example, studies in the midAtlantic region looking at tomatoes found a prevalence rate of $9.5 \%$, and a rate of $6 \%$ for leafy green (Marine et al., 2015; Pagadala et al., 2015). However, comparisons of our findings with those from other studies need to account for the types of produce (e.g., root vegetables, leafy greens, and fruits), which are known from previous reports to have increased propensity for contamination (Harvey et al., 2016; Ferrelli and Micallef, 2019). In addition, soil proximity, and factors such as farming system, planting practices (e.g., mulch, irrigation type), spatial-temporal differences, and diagnostic detection limits may differ between farms and studies (Castro-Ibanez et al., 2015; Marine et al., 2015; Pagadala et al., 2015; Park et al., 2015). In our studies, other sources of potential contamination of fresh produce could not be ruled out, e.g., wildlife intrusion (even if samples were collected without indication of wildlife fecal contamination), run-off from soil amendments (participant farms had a good separation of BSSAO storage), and agricultural water (low prevalence of generic E. coli in surveyed farms).

\section{Pathogen Detection in Manure}

The unique feature of this multi-regional study is the determination of foodborne pathogen prevalence in naturally contaminated untreated manure from more than three species (cattle, horse, poultry, small ruminants and swine) in commercial, certified organic systems. The majority of the naturally contaminated manure surveys are either focused one animal species, or on one or two foodborne pathogens with limited monitoring periods after incorporation into the soil. During this multi-regional study, $63.2 \%$ of the NOP-certified organic farms were positive for at least one of the tested foodborne pathogens, with farm clustering. We also were able to detect foodborne pathogens across the animal species and different manure ages and compost samples. The highest prevalence of pathogens we detected in manure was observed for non-O157 STEC in untreated manure samples from ruminants, followed by Salmonella spp. in ruminants and poultry, but horse samples tested positive only for L. monocytogenes. These findings are in agreement with other studies that also reported a wide range of foodborne pathogen prevalence which was associated with the animal manure source (e.g., species, season, diet and husbandry, intermittent shedding in natural reservoirs) and type of feedstocks/bedding used (Hutchison et al., 2004; Ingham et al., 2005; Jay et al., 2007; Sinton et al., 2007; Moriarty et al., 2011; Berry et al., 2013; Erickson et al., 2014, 2015). Variation in management practices among the farms may reflect the spatial-temporal clustering of positive samples, highlighting the importance of surveying multiple farms and conducting multi-year studies. 


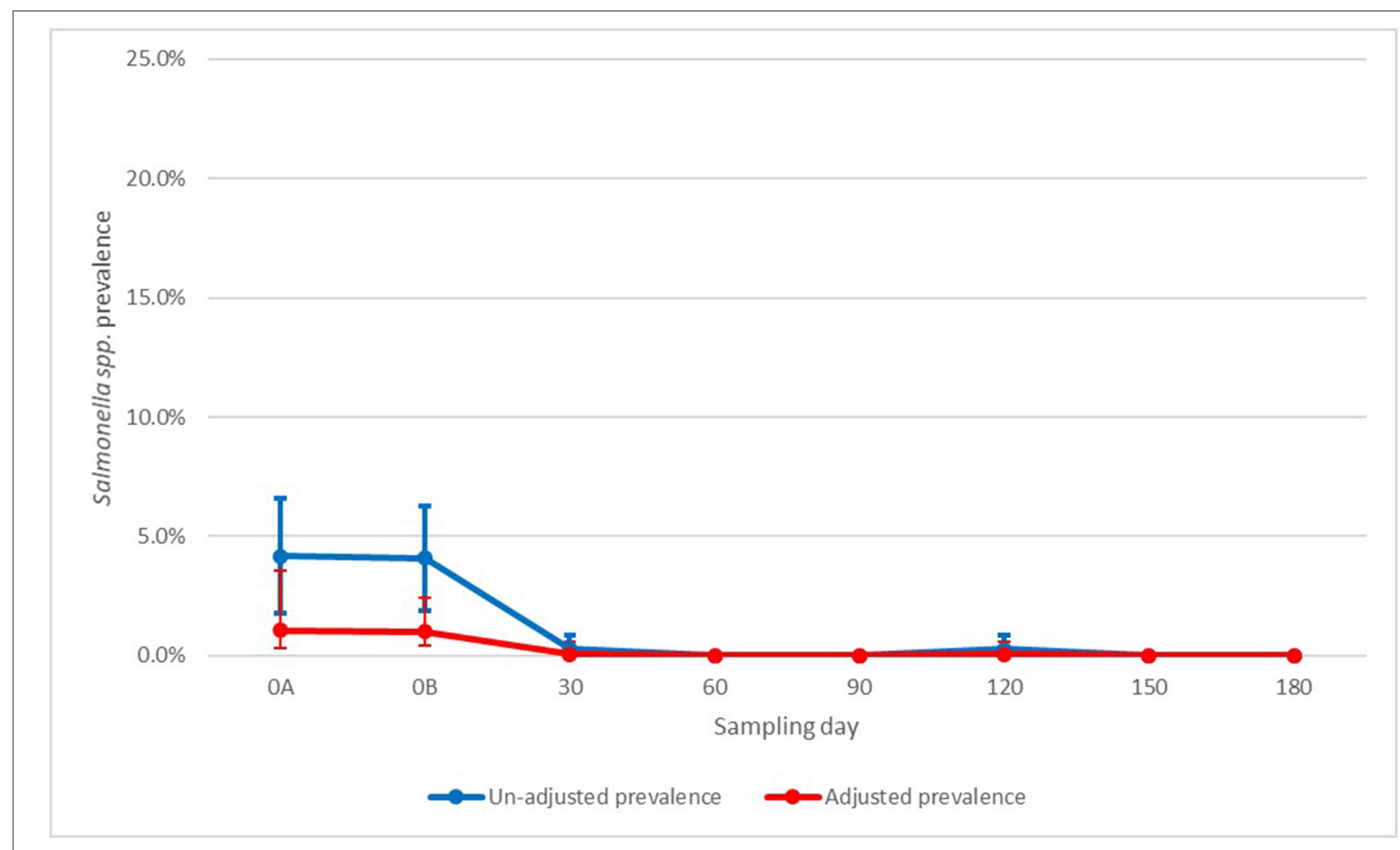

FIGURE 3 | Un-adjusted and adjusted apparent prevalence of Salmonella spp in soil by sampling day with 95\% confidence intervals collected in a longitudinal study in certified organic farms.

However, we found infrequent (low) E. coli O157:H7 prevalence (1.3\%), in only poultry and mixed manure samples, whereas other studies reported a prevalence of $15.4 \%$ in solid bovine manure from a multi-county survey in California (Chen et al., 2019) and $19 \%$ in bovine manure (multiple storage type and ages) in the Southeastern region of the US (Baker et al., 2019). Cattle and other ruminants are commonly considered to be natural reservoirs for non-O157 STEC, with cattle being the major reservoir of E. coli O157:H7 (Hutchison et al., 2005; Jay et al., 2007; Berry et al., 2015, 2019). Such discrepancies regarding prevalence might be because of different farms sizes. The California and Southeastern studies have targeted conventional and big dairy farms, which has a higher reported prevalence of foodborne pathogens competed to for small-to medium-scale and diversified farms (Pires et al., 2019), which were surveyed in the present study.

Salmonella was the second most frequent pathogen detected in manure samples (7.3\%). Salmonella was detected in cattle, poultry, and mixed manure. Similar Salmonella prevalence (6.6\%) was reported on dairy farm operations in California (Chen et al., 2019), while a much higher prevalence was reported in wet $(26.6 \%)$ and dry $(23.7 \%)$ poultry litter in Virginia farms (Gu et al., 2018). However, Pires et al. (2019) reported a much lower overall prevalence $(1.19 \%)$ in fecal samples collected from diversified small-scale farms from four California farm regions (Pires et al., 2019). Most of the participants' farms in the present study were considered small-to medium-scale farms across the four regions. These discrepancies may be due to differences in geography, the climate, farm management, manure management (e.g., storage and age of manure), livestock species, and diet management (Strawn et al., 2013b; Millner et al., 2014; Gu et al., 2018, 2019; Pires et al., 2019).

\section{Pathogens in Soil}

This is the first longitudinal study to our knowledge to assess the prevalence and persistence of four foodborne pathogens in soil amended with naturally contaminated and untreated manure from more than three animal species (cattle, horse, poultry, small ruminants and swine), with a prolonged follow-up of the soils, up to 180 days post-application, in NOP certified and commercial organic farms from four regions. The majority of on-farm studies have been conducted on conventional farms, limited to one region, source of manure type, type of crop or one to two foodborne pathogens, and with short period of follow-up post manure application (Natvig et al., 2002; Ingham et al., 2005; Gu et al., 2018, 2019; Sheng et al., 2019). Although the overall foodborne pathogen prevalence in manure was $18 \%$, the adjusted soil prevalence did not exceed $10 \%$ for a given pathogen (exception for non-O157 STEC on 2017, 11.9\%), state, or manure source.

Regarding the overall $L$. monocytogenes prevalence in soil, our findings also are consistent with previous studies conducted in New York, where L. monocytogenes was the most 


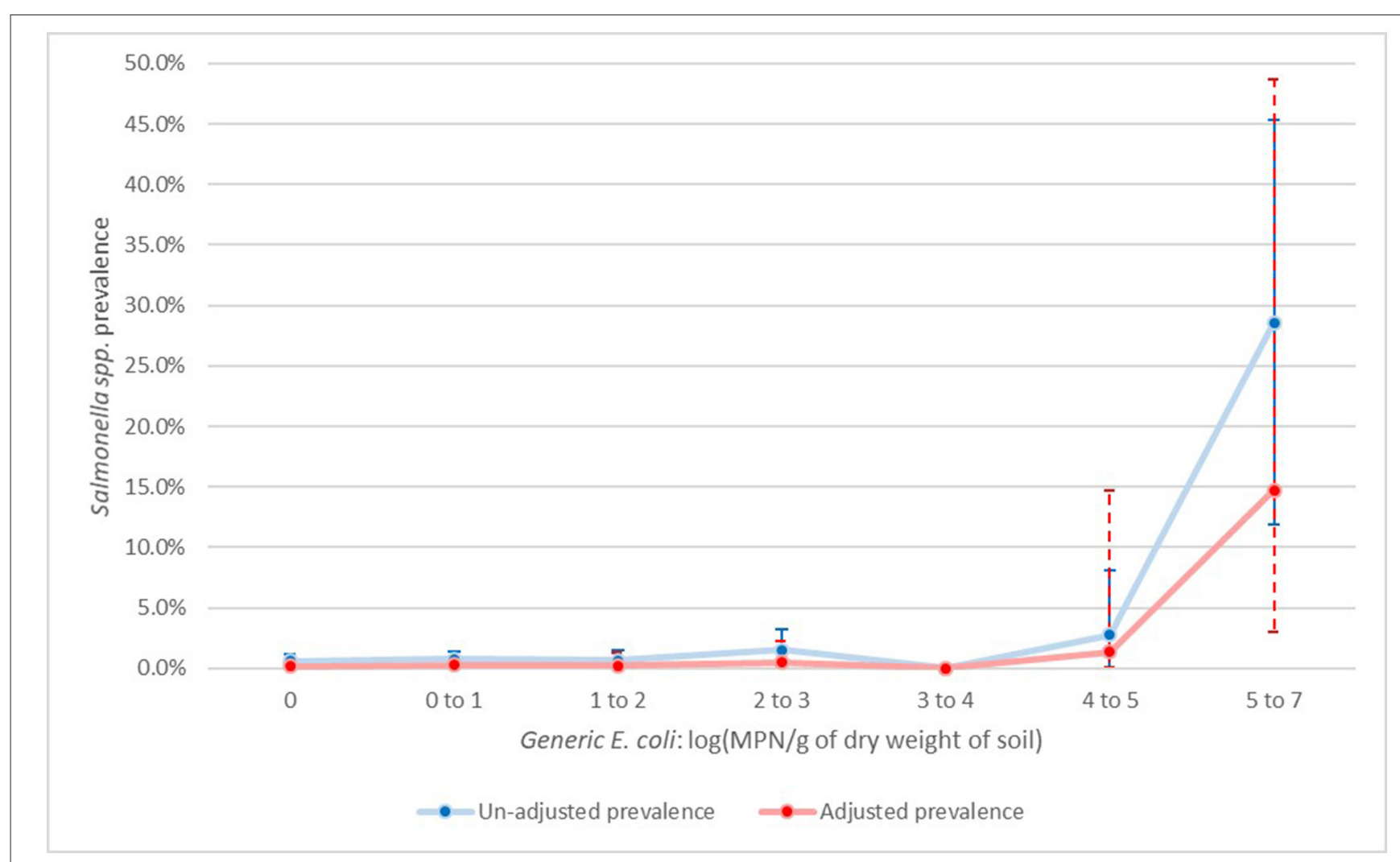

FIGURE 4 | Un-adjusted and adjusted apparent prevalence of Salmonella by levels of generic $E$. coli in soil (log (MPN/g of dry soil) with $95 \%$ confidence intervals collected in a longitudinal study in certified organic farms.

common foodborne pathogen isolated from produce production environments, including soil samples (Strawn et al., 2013a,b; Weller et al., 2015a,b). In a cross-sectional study in New York, $9.7 \%$ of the soil and drag swab samples were positive (Strawn et al., 2013b), similarly, Weller et al. (2015b) reported an $8 \%$ prevalence in soil in a longitudinal study in New York. In contrast, in our study a higher prevalence of STEC $(7.7 \%)$ was observed in the soil amended with manure compared to that on the New York farms. Weller et al. (2015a) reported a STEC prevalence of $5 \%$ in terrestrial samples in a longitudinal study over 6 weeks on ten produce farms in New York. In a 2-year longitudinal study on five produce farms in New York, nonO157 STEC were isolated in 2.7\% of the tested samples (soil, water, feces, and drag swabs) (Strawn et al., 2013a). On other hand, neither Salmonella nor non-O157 STEC was identified in production areas of tomatoes fields from small and mediumsized farms in the mid-Atlantic region, including conventional and organic production systems (Pagadala et al., 2015).

Over-time there was a significantly decreased prevalence of pathogens in the soil, reaching pre-application (d0A) prevalence (less 5\% for non-O157 STEC and L. monocytogenes) or zero (Salmonella) at 90-days post-application. This shows the relatively infrequent (low) likelihood of pathogen survival (prevalence) in soils amended with untreated manure in studied farms.
In our study, non-O157 STEC and L. monocytogenes positive soil samples were identified after 90-and 120-days post-manure application and incorporation. Soil amended with cattle and small ruminant manure had the highest adjusted $L$. monocytogenes prevalence. Moreover, L. monocytogenes adjusted apparent prevalence and un-adjusted apparent prevalence values in soil were similar, which shows a much lower on-farm clustering and wide distribution in the soil environment of participating farms. Because Listeria spp. are naturally occurring soilborne microorganisms, their presence is not suprising, but understanding what increases their presence and persistance may aid development of strategies to avoid their proliferation.

The majority of the studies examining the survival of pathogens such as non-O157 STEC or Salmonella spp. in soil amended with manure have been conducted in experimental plots and with inoculated manure, reporting variations of the persistence depending on manure type, inoculation dose, and soil type (Franz et al., 2008; Nyberg et al., 2014; Sharma et al., 2016, 2019). In a Dutch study, E. coli O157:H7 survived in manure-amended soils that were both managed organically and conventionally for 78 and 84 days in loamy and sandy soils, respectively (Franz et al., 2008). In another study, Salmonella enterica serovar Typhimurium was detected up to 150 days after cattle slurry manure application (Nyberg et al., 2014). Longer survival was reported in soils amended with poultry litter, as 


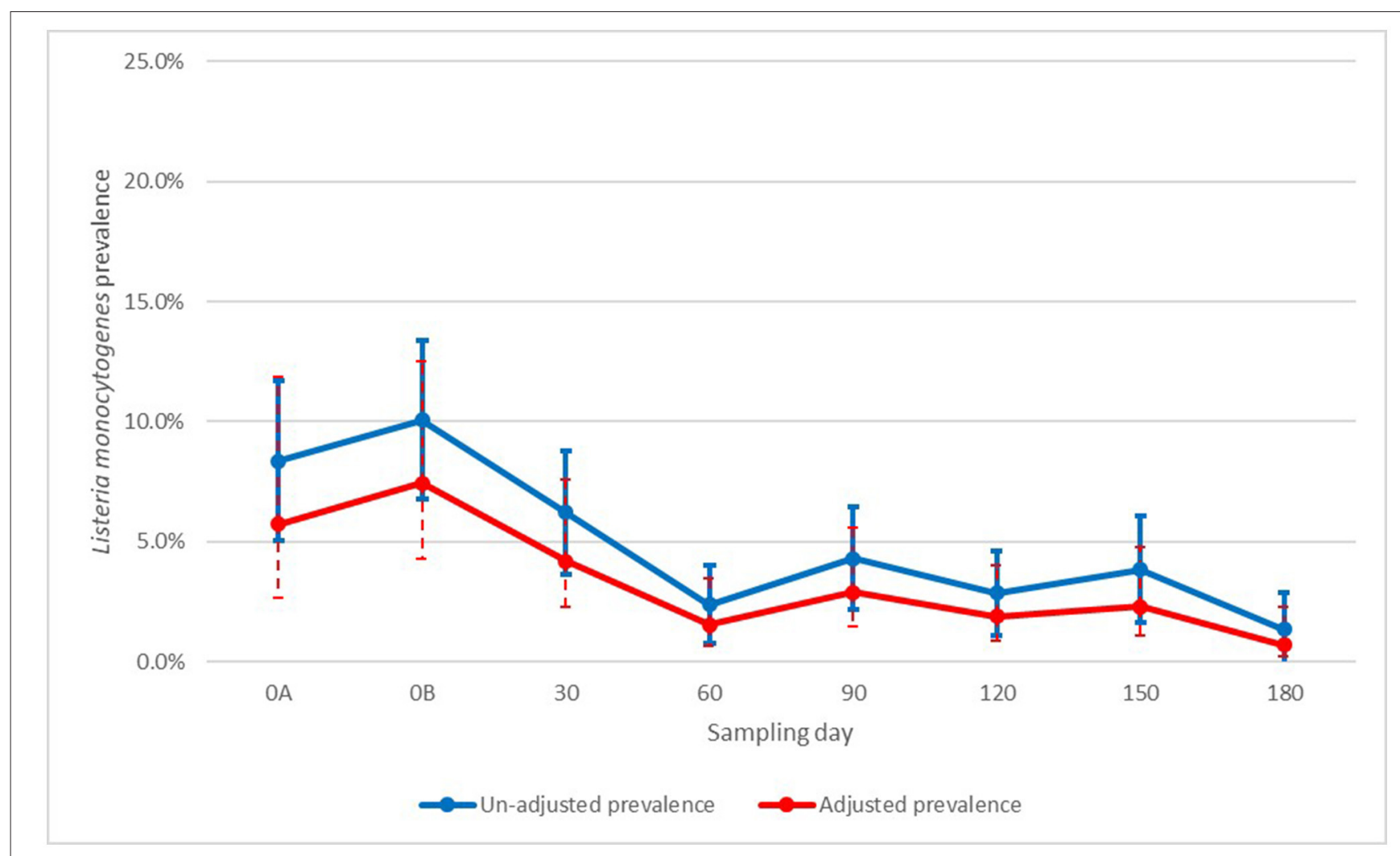

FIGURE 5 | Un-adjusted and adjusted apparent prevalence of Listeria monocytogenes in soil by sampling with 95\% Confidence intervals collected in a longitudinal study in certified organic farms.

Salmonella survived up to 4 to 6 months post-application in a major agricultural area of Virginia under natural contamination conditions ( $\mathrm{Gu}$ et al., 2019). In contrast, in a study assessing the microbial safety of dairy manure in raspberry production, L. monocytogenes and non-O157 STEC were not detected, while Salmonella was isolated in the soil right after the application of manure-based BSAAO (i.e., raw manure straight lagoon, anaerobically digested dairy manure products, and digested liquid effluent), but not detected in soil after 2 or 4 months after application (Sheng et al., 2019). These aforementioned studies show that persistence in soil depends on the pathogen, manure source, soil type, environmental conditions, and region. Although, comparisons among experimental studies is difficult because of the use of different experiment set-ups, production systems, and geographic locations, higher survival of pathogens in soil amended with poultry and cattle manures is in agreement with other studies.

While each farm is characterized by unique features and situations, several factors (e.g., landscape, agricultural practices, environmental factors) are major influences on pathogen prevalence and persistence of L. monocytogenes and Salmonella in produce fields and agricultural environments (Strawn et al., 2013a,b; Chapin et al., 2014; Weller et al., 2015a,b). However, comparisons between studies should be done cautiously, and include if possible longitudinal study periods that extend sampling the same plots up to 180 days post-manure application to detect the likelihood of viable foodborne pathogen increases over-time. Moreover, the use of BSAAOs was not investigated in these aforementioned studies (Strawn et al., 2013a,b; Chapin et al., 2014; Weller et al., 2015a,b), nor was the time interval between application of manure and harvest of the crops.

Interestingly, not all farms that had pathogen-positive soil samples had positive manure samples. Only two to five farms (depending on the year and pathogen) out of 19 farms had positive manure and positive soil samples, indicating other potential sources of pathogen introduction into soil than BSAAO. However, non-O157 STEC and L. monocytogenes positive soil samples were identified 90-and 120-days postmanure application and incorporation. The present study design has not allowed the tracing of strains to the manure sources, nor assignment to other potential sources, such as contamination by birds and other wildlife (Ingham et al., 2005). In addition to this limitation to directly link soil to manure isolates, other potential explanations for isolation of pathogens over the 120 days post-application of BSAAO could be pathogen regrowth related to agricultural practices (e.g., top-dressing organic fertilizer, bed cultivation, overhead irrigation) or other environmental conditions (precipitation). These factors were recorded and will be included in a predictive model assessing the risks factors associated with the likelihood of pathogen 


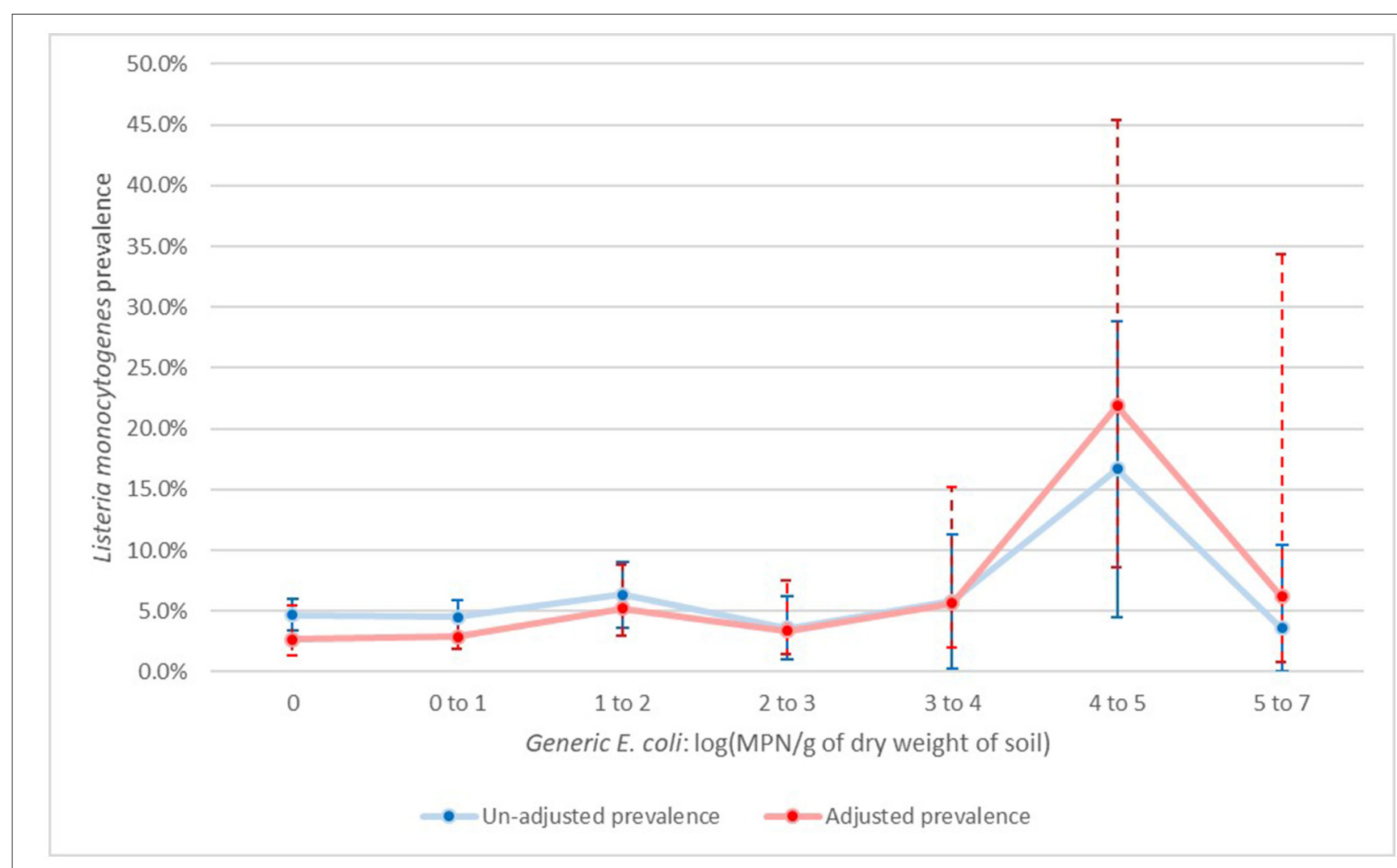

FIGURE 6 | Un-adjusted and adjusted apparent prevalence of Listeria monocytogenes in soil by levels of generic E. coli (log (MPN/g of dry soil)) with 95\% confidence intervals collected in a longitudinal study in certified organic farms.

presence. Another limitation of the current study is that it is an on-farm observational study, and therefore, no interventions were conducted compared to experimental trials, with known and inoculated pathogen contamination of the manure. This observational study was representative of the type of farms using untreated manure in organic production and allowed for the monitoring of pathogen persistence in the soil, representing diverse manure use across four states. However, it was an unbalanced study design (i.e., not all farms used the same type of manure or grew the same vegetables), which may have limited some of the findings to certain farms with different agricultural practices.

In contrast to our study, which did not detect any foodborne pathogens in tested irrigation water, several studies found relatively high Salmonella spp. (4\% and 12\%), non-O157 STEC (3\%), and L. monocytogenes (9\%, 30\%, and 63\%) in agricultural water, including irrigation water (Strawn et al., 2013b; Weller et al., 2015a,b). Potential explanations for differences in prevalence in different samples (soil and water samples) can be due to spatial-temporal differences, farm and manure management (manure application, cultivation, buffer zones, etc.), irrigation water, meteorological factors and water sampling and testing protocols (total of tested samples, sediment testing vs. water, etc.) across the different regions and studies (Strawn et al., 2013a,b; Weller et al., 2015a,b; Gu et al., 2018).

\section{Aged Manure Use, Manure Processing and Storage}

The majority of the farms in this study (14 out of 19), used aged manure with a range of age from 2 months up to 2 years. Some of the farms applied BSAAO from minimally managed manure piles where no temperature or turning records were kept, as no record keeping of temperature or number of turns was kept (only two out of 19 farms used in-house composting with records). Since these minimally managed piles were considered as untreated BSAAO, the data was combined with the other untreated manure data. Untreated manure, such as aged manure and minimally managed piles, were frequently reported as common BSAAO used in organic produce production, and farmers frequently considered aged manure as a "composting process" in two nationwide surveys (Nsac, 2016; Pires et al., 2018; Ramos et al., 2019).

While FSMA PSR guidelines currently exist for treated BSAAO, such as those that undergo a scientifically validated treatment (e.g., composting), aged manure and minimally managed piles do not fit any of these categories and are considered untreated BSAAO (FDA, 2015, 2018). Untreated BSAAO may be associated with potential contamination of fresh produce through direct or indirect contact with foodborne pathogens found in incompletely finished or unfinished composted animal fecal material (Berry et al., 2013; Millner et al., 
2014). Although the application intervals for untreated BSAAO are currently reserved by FDA in the FSMA PSR, growers are encouraged to comply with the 90-and 120-day application interval prescribed in the USDA NOP.

Management of manure during storage and proximity to vegetable fields along with slope and potential for runoff, dust and pest/animal movements from the manure storage to crop fields is an important feature to consider on farm sites where untreated and aged manure is being staged and aged (Berry et al., 2015, 2019; Alegbeleye et al., 2018). The majority of the farmers reported storing manure in piles, some of which were minimally managed through turning. Some manure piles were topped off with new manure from animals on the farm (Pires et al., 2018). These practices may re-introduce pathogens and thereby prolong the time needed to allow for any pathogens to die-off in the manure piles.

\section{CONCLUSIONS}

In this multi-regional, longitudinal study, we investigated the natural prevalence and persistence of four foodborne pathogens (non-O157 STEC, E. coli O157:H7, Salmonella spp., and L. monocytogenes) in soil amended with untreated manure and assessed the presence of pathogens in harvestable crops from NOP certified organic fresh produce farms. This longitudinal study design was conducted over 21 months to capture two crop cycles and time-dependent factors in four regions in the US (California, Minnesota, Maine, and Maryland). Pathogen contamination on fresh produce was found to be infrequent and $<1 \%$ in this study. The prevalence of non-O157 STEC and Salmonella, in untreated/raw manure was considerably higher than E. coli O157:H7 and L. monocytogenes, while in soil amended with untreated manure, a higher prevalence was observed for non-O157 STEC and L. monocytogenes. Foodborne pathogen prevalence in the soil peaked after manure application and decreased significantly 30 days post-application. Non-O157 STEC and L. monocytogenes positive soil samples were identified after 90 -and 120-days post-manure application and incorporation.

Results from this study did not demonstrate a significant presence of foodborne pathogens in produce from soils amended with untreated BSAAO. However, these data cannot be generalized outside of the organic sector or this study, as the low rate of pathogen presence on produce may be due in part to compliance with wait-time regulations for organic crop production, and reflect microbial and environmental conditions in open-field production systems, including organic ones (Ivanek et al., 2009; Strawn et al., 2013a, b). Therefore, future research focusing on tracing of pathogens can provide enhanced understanding of primary risks for pathogen introduction and their integration of the effects of environmental factors present in organic systems and potential leverage points where those risk processes can be mitigated.

Our study also provides multi-regional baseline data relating to current NOP wait-time rules. The use of BSAAO, such as livestock manure, in certified organic farms in the USA is an important source of fertilizer for the production of crops (United States Department of Agriculture National Organic Program, 2011a; Sharma and Reynnells, 2016) because the use of synthetic fertilizer is prohibited on organic farms (United States Department of Agriculture National Organic Program, 2011a,b). Therefore, additional research is needed on risk factors related to the soil management practices and meteorological factors associated with persistence of foodborne pathogens, because, while we found that soil pathogen prevalence decreased significantly 30 -and 60 -days post-application, we also found that non-O157 STEC and L. monocytogenes can persist in soil beyond the NOP standards for wait-times (90/120 days). Transfer to crop and subsequent handling, storage, distribution, and shelf-life conditions need to be factored into the ultimate impact of even low and or infrequent pathogen contamination of produce on the potential for post-harvest pathogen survival and increase. Identification of potential risk factors influencing foodborne pathogen persistence in preharvest produce cropping environments for soils amended with untreated and raw manure in organic production systems will be used to develop mitigation strategies that reduce food safety risks while promoting sustainability of organic agriculture systems.

\section{DATA AVAILABILITY STATEMENT}

The datasets generated for this study are available by request to the corresponding author.

\section{AUTHOR CONTRIBUTIONS}

MJ-R, PM, JS, PP, MH, BM-L, and AP: conceived the project, designed the study and wrote the grant. PM, PP, MH, FH, and AP: coordinated the efforts between the CA, MN, MD, and ME teams. AP: oversaw the day-to-day aspects of the project. MJ-R, PM and AP: oversaw the laboratory work. TR, JS, JL, NR, VH, PA, and AK: carried out the field work and sampling collection. TR, JS, VH, and PA: carried out the laboratory work. JNB, BM-L, and AP: developed the data analysis plan, which JNB implemented. TR, JNB, VH, and AP: wrote the first draft of the manuscript. All authors contributed to manuscript revision, and read and approved the final manuscript.

\section{FUNDING}

This work was funded by the Organic Agriculture Research and Extension Initiative (OREI), National Institute of Food and Agriculture, U.S. Department of Agriculture, under award number 2016-51300-25724.

\section{ACKNOWLEDGMENTS}

We acknowledge Carolyn Chandler, Amanda Taylor, Zoe Scholar, Deonnie Huang, Rachel Hawkins, Amy Patamakomol, and Ka Man Woo for assistance in the laboratory and field work as well as Tracy Misiewicz from The Organic Center for assistance with farmer recruitment. We would like to thank all the participating farms. 


\section{REFERENCES}

Alegbeleye, O. O., Singleton, I., and Sant'ana, A. S. (2018). Sources and contamination routes of microbial pathogens to fresh produce during field cultivation: a review. Food Microbiol. 73, 177-208. doi: $10.1016 / \mathrm{j} . \mathrm{fm} .2018 .01 .003$

Atwill, E. R., Chase, J.A., Oryang, D., Bond, R.F., Koike, S.T., Cahn, M. D., et al. (2015). Transfer of Escherichia coli O157:H7 from simulated wildlife scat onto romaine lettuce during foliar irrigation. J. Food Prot. 78, 240-247. doi: 10.4315/0362-028X.JFP-14-277

Baker, C. A., De, J., Bertoldi, B., Dunn, L., Chapin, T., Jay-Russell, M., et al. (2019). Prevalence and concentration of stx + E. coli and E. coli O157 in bovine manure from Florida farms. PLoS ONE. 14, e0217445-e0217445. doi: 10.1371/journal.pone.0217445

Bates, D., Machler, M., Bolker, B. M., and Walker, S. C. (2015). Fitting linear mixedeffects models using lme4. J. Stat. Softw. 67, 1-48. doi: 10.18637/jss.v067.i01

Baur, P. (2020). When farmers are pulled in too many directions: comparing institutional drivers of food safety and environmental sustainability in California agriculture. Agric. Human Values. 37, 1175-1194. doi: $10.1007 /$ s10460-020-10123-8

Berry, E.D., Millner, P.D., Wells, J.E., Kalchayanand, N., and Guerini, M. N. (2013). Fate of naturally occurring Escherichia coli O157:H7 and other zoonotic pathogens during minimally managed bovine feedlot manure composting processes. J. Food Prot. 76, 1308-1321. doi: 10.4315/0362-028X.JFP-12-364

Berry, E. D., Wells, J. E., Bono, J. L., Woodbury, B. L., Kalchayanand, N., Norman, K. N., et al. (2015). Effect of proximity to a cattle feedlot on Escherichia coli O157:H7 contamination of leafy greens and evaluation of the potential for airborne transmission. Appl. Environ. Microbiol. 81, 1101-1110. doi: 10.1128/AEM.02998-14

Berry, E. D., Wells, J. E., Durso, L. M., Friesen, K. M., Bono, J. L., and Suslow, T. V. (2019). Occurrence of Escherichia coli O157:H7 in pest flies captured in leafy greens plots grown near a beef cattle feedlot. J. Food Prot. 82, 1300-1307. doi: 10.4315/0362-028X.JFP-18-601

Castro-Ibanez, I., Gil, M. I., Tudela, J. A., Ivanek, R., and Allende, A. (2015). Assessment of microbial risk factors and impact of meteorological conditions during production of baby spinach in the Southeast of Spain. Food Microbiol. 49, 173-181. doi: 10.1016/j.fm.2015.02.004

Center for Disease Control (2016). List of Selected Multistate Foodborne Outbreak Investigations. Available online at: http://www.cdc.gov/foodsafety/outbreaks/ multistate- outbreaks/outbreaks-list.html (accessed March 2, 2016).

Chapin, T. K., Nightingale, K. K., Worobo, R. W., Wiedmann, M., and Strawn, L. K. (2014). Geographical and meteorological factors associated with isolation of Listeria species in New York state produce production and natural environments. J. Food Prot. 77, 1919-1928. doi: 10.4315/0362-028X.JFP-14-132

Chen, J., and Griffiths, M. W. (1998). PCR differentiation of Escherichia coli from other gram-negative bacteria using primers derived from the nucleotide sequences flanking the gene encoding the universal stress protein. Lett. Appl. Microbiol. 27, 369-371. doi: 10.1046/j.1472-765X.1998.00445.x

Chen, Z., Biswas, S., Aminabadi, P., Stackhouse, J. W., Jay-Russell, M. T., and Pandey, P. K. (2019). Prevalence of Escherichia coli O157 and Salmonella spp. in solid bovine manure in California using real-time quantitative PCR. Lett. Appl. Microbiol. 69, 23-29. doi: 10.1111/lam.13156

Cooley, M. B., Jay-Russell, M., Atwill, E. R., Carychao, D., Nguyen, K., Quinones, B., et al. (2013). Development of a robust method for isolation of shiga toxinpositive Escherichia coli (STEC) from fecal, plant, soil and water samples from a leafy greens production region in California. PLoS ONE. 8:e65716. doi: 10.1371/journal.pone.0065716

Cooley, M. B., Quinones, B., Oryang, D., Mandrell, R. E., and Gorski, L. (2014). Prevalence of shiga toxin producing Escherichia coli, Salmonella enterica, and Listeria monocytogenes at public access watershed sites in a California central coast agricultural region. Front. Cell Infect. Microbiol. 4:30. doi: 10.3389/fcimb.2014.00030

Curiale, M. (2004). MPN Calculator. Available online at: http://www.i2workout. com/mcuriale/mpn/index.html (accessed July 25, 2019).

Denis, N., Zhang, H., Leroux, A., Trudel, R., and Bietlot, H. (2016). Prevalence and trends of bacterial contamination in fresh fruits and vegetables sold at retail in Canada. Food Control. 67, 225-234. doi: 10.1016/j.foodcont.2016.02.047
Dewey-Mattia, D., Manikonda, K., Hall, A. J., Wise, M. E., and Crowe, S. J. (2018). Surveillance for foodborne disease outbreaks-United States, 2009-2015. MMWR Surveill. Summ. 67, 1-11. doi: 10.15585/mmwr.ss6710a1

Erickson, M. C., Liao, J., Jiang, X. P., and Doyle, M. P. (2014). Inactivation of pathogens during aerobic composting of fresh and aged dairy manure and different carbon amendments. J. Food Prot. 77, 1911-1918. doi: 10.4315/0362-028X.JFP-14-194

Erickson, M. C., Smith, C., Jiang, X. P., Flitcroft, I. D., and Doyle, M. P. (2015). Manure source and age affect survival of zoonotic pathogens during aerobic composting at sublethal temperatures. J. Food Prot. 78, 302-310. doi: 10.4315/0362-028X.JFP-14-288

FDA (2015). Federal Register, Department of Health and Human Services. Available online at: https://www.federalregister.gov/documents/2015/11/27/ 2015-28159/standards-for-the-growing-harvesting-packing-and-holding-ofproduce-for-human-consumption

FDA (2016). Federal Register, Department of Health and Human Services. Available online at: https://www.federalregister.gov/documents/2016/03/04/201604712/risk-assessment-of-foodborne-illness-associated-with-pathogensfrom-produce-grown-in-fields-amended

FDA (2018). Federal Register, Department of Health and Human Services. Available online at: https://www.federalregister.gov/documents/2018/11/01/ 2018-23868/standards-for-the-growing-harvesting-packing-and-holding- ofproduce-for-human-consumption-draft

Ferrelli, A. M. C., and Micallef, S. A. (2019). "Chapter 7: food safety risks and issues associated with farming and handling practices for organic certified fresh produce," in Safety and Practice for Organic Food, eds D. Biswas and S. A. Micallef (Cambridge, MA: Academic Press), 151-180. doi: 10.1016/B978-0-12-812060-6.00007-6

Food and Drug Administration (2018a). Bacteriological Analytical Manual (BAM) Chapter 5: Salmonella. Available onlone at: https://www.fda. gov/food/laboratory-methods-food/bam-chapter-10-detection-listeriamonocytogenes-foods-and-environmental-samples-and-enumeration (accessed March 8, 2016).

Franz, E., Semenov, A. V., Termorshuizen, A. J., De Vos, O. J., Bokhorst, J. G., and Van Bruggen, A. H. (2008). Manure-amended soil characteristics affecting the survival of E. coli O157:H7 in 36 Dutch soils. Environ. Microbiol. 10, 313-327. doi: 10.1111/j.1462-2920.2007.01453.x

Franz, E., Van Diepeningen, A. D., De Vos, O. J., and Van Bruggen, A. H. (2005). Effects of cattle feeding regimen and soil management type on the fate of Escherichia coli O157: H7 and Salmonella enterica serovar Typhimurium in manure, manure-amended soil, and lettuce. App. Environ. Microbiol. 10, 6165-6174. doi: 10.1128/AEM.71.10.6165-6174.2005

Gu, G., Strawn, L.K., Zheng, J., Reed, E. A., and Rideout, S. L. (2019). Diversity and dynamics of Salmonella enterica in water sources, poultry litters, and field soils amended with poultry litter in a major agricultural area of Virginia. Front. Microbiol. 10:2868. doi: 10.3389/fmicb.2019.02868

Gu, G., Strawn, L. K., Oryang, D. O., Zheng, J., Reed, E.A., Ottesen, A. R., et al. (2018). Agricultural practices influence Salmonella contamination and survival in pre-harvest tomato production. Front. Microbiol. 9:2451. doi: $10.3389 /$ fmicb.2018.02451

Harvey, R. R., Zakhour, C. M., and Gould, L. H. (2016). Foodborne disease outbreaks associated with organic foods in the United States. J. Food Prot. 79, 1953-1958. doi: 10.4315/0362-028X.JFP-16-204

Hogg, R. V., Tanis, E. A., and Zimmerman, D. L. (2015). Probability and Statistical Inference, 9th Edn. Essex: Pearson Education.

Hutchison, M. L., Walters, L. D., Avery, S. M., Munro, F., and Moore, A. (2005). Analyses of livestock production, waste storage, and pathogen levels and prevalences in farm manures. Appl. Environ. Microbiol. 71, 1231-1236. doi: 10.1128/AEM.71.3.1231-1236.2005

Hutchison, M. L., Walters, L. D., Avery, S. M., Synge, B. A., and Moore, A. (2004). Levels of zoonotic agents in British livestock manures. Lett. Appl. Microbiol. 39, 207-214. doi: 10.1111/j.1472-765X.2004.01564.x

Ingham, S.C., Fanslau, M.A., Engel, R. A., Breuer, J.R., Wright, T. H., Reith-Roselle, J. K., et al. (2005). Evaluation of fertilization-to-planting and fertilization-to-harvest intervals for safe use of noncomposted bovine manure in Wisconsin vegetable production. J. Food Prot. 68, 1134-1142. doi: 10.4315/0362-028X-68.6.1134 
Ingham, S. C., Losinski, J. A., Andrews, M. P., Breuer, J. E., Breuer, J. R., Wood, T.M., et al. (2004). Escherichia coli contamination of vegetables grown in soils fertilized with non-composted bovine manure: garden-scale studies. Appl. Environ. Microbiol. 70, 6420-6427. doi: 10.1128/AEM.70.11.6420-6427.2004

Ivanek, R., Grohn, Y.T., Wells, M. T., Lembo, A.J., Sauders, B. D., and Wiedmann, M. (2009). Modeling of spatially referenced environmental and meteorological factors influencing the probability of Listeria species isolation from natural environments. Appl. Environ. Microbiol. 75, 5893-5909. doi: 10.1128/AEM.02757-08

Jay, M. T., Cooley, M., Carychao, D., Wiscomb, G.W., Sweitzer, R. A., CrawfordMiksza, L., et al. (2007). Escherichia coli O157:H7 in feral swine near spinach fields and cattle, Central California coast. Emerg. Infect. Dis. 13, 1908-1911. doi: $10.3201 /$ eid1312.070763

Jay-Russell, M. T., Madigan, J. E., Bengson, Y., Madigan, S., Hake, A. F., Foley, J. E., et al. (2014). Salmonella Oranienburg isolated from horses, wild turkeys and an edible home garden fertilized with horse raw manure. Zoonoses Public Health. 61, 64-71. doi: 10.1111/zph.12043

Karp, D. S., Moses, R., Gennet, S., Jones, M. S., Joseph, S., M'gonigle, L. K., et al. (2016). Agricultural practices for food safety threaten pest control services for fresh produce. J. Appl. Ecol. 53, 1402-1412. doi: 10.1111/1365-2664.12707

Kawasaki, S., Horikoshi, N., Okada, Y., Takeshita, K., Sameshima, T., and Kawamoto, S. (2005). Multiplex PCR for simultaneous detection of Salmonella spp., Listeria monocytogenes, and Escherichia coli O157:H7 in meat samples. J. Food Prot. 68, 551-556. doi: 10.4315/0362-028X-68.3.551

Kuan, C.-H., Rukayadi, Y., Ahmad, S.H., Wan Mohamed Radzi, C. W. J., Thung, T.-Y., Premarathne, J. M. K. J. K., et al. (2017). Comparison of the microbiological quality and safety between conventional and organic vegetables sold in Malaysia. Front. Microbiol. 8:1433. doi: 10.3389/fmicb.2017.01433

Marine, S. C., Pagadala, S., Wang, F., Pahl, D. M., Melendez, M.V., Kline, W.L., et al. (2015). The growing season, but not the farming system, is a food safety risk determinant for leafy greens in the Mid-Atlantic region of the United States. Appl. Environ. Microbiol. 81, 2395-2407. doi: 10.1128/AEM.00051-15

Millner, P., Ingram, D., Mulbry, W., and Arikan, O. A. (2014). Pathogen reduction in minimally managed composting of bovine manure. Waste Manag. 34, 1992-1999. doi: 10.1016/j.wasman.2014.07.021

Moriarty, E. M., Mackenzie, M. L., Karki, N., and Sinton, L. W. (2011). Survival of Escherichia coli, Enterococci, and Campylobacter spp. in sheep feces on pastures. Appl. Environ. Microbiol. 77, 1797-1803. doi: 10.1128/AEM.01329-10

Mukaka, M. M (2012). Statistics corner: a guide to appropriate use of correlation coefficient in medical research. Malawi Med. J. 24, 69-71. Available online at: https:/www.ncbi.nlm.nih.gov/pmc/articles/PMC3576830/

Natvig, E. E., Ingham, S.C., Ingham, B. H., Cooperband, L. R., and Roper, T. R. (2002). Salmonella enterica serovar Typhimurium and Escherichia coli contamination of root and leaf vegetables grown in soils with incorporated bovine manure. Appl. Environ. Microbiol. 68, 2737-2744. doi: 10.1128/AEM.68.6.2737-2744.2002

Nightingale, K.K., Schukken, Y. H., Nightingale, C. R., Fortes, E. D., Ho, A. J., Her, Z., et al. (2004). Ecology and transmission of Listeria monocytogenes infecting ruminants and in the farm environment. Appl. Environ. Microbiol. 70, 4458-4467. doi: 10.1128/AEM.70.8.4458-4467.2004

Nsac, N.S.a.C. (2016). Comments to FDA's Biological Soil Amendments of Animal Origin Risk Assessment Docket. Washington, DC: National Sustainable Agriculture Coalition.

Nyberg, K.A., Ottoson, J. R., Vinnerås, B., and Albihn, A. (2014). Fate and survival of Salmonella typhimurium and Escherichia coli O157:H7 in repacked soil lysimeters after application of cattle slurry and human urine. J. Sci. Food Agric. 94, 2541-2546. doi: 10.1002/jsfa.6593

Olaimat, A. N., and Holley, R. A. (2012). Factors influencing the microbial safety of fresh produce: a review. Food Microbiol. 32, 1-19. doi: 10.1016/j.fm.2012.04.016

Organic Trade Association (2015). "Biological Soil Amendments of Animal Origin: Impact of FDA's Proposed Application Intervals on Organic Fertility and Crop Rotation Requirements," in OTA Comments to FDA, Appendix A (Washington, DC: OTA), $1-8$.

Ozlu, E., and Kumar, S. (2018). Response of soil organic carbon, pH, electrical conductivity, and water stable aggregates to long-term annual manure and inorganic fertilizer. Soil Sci. Soc. Am. J. 82, 1243-1251. doi: $10.2136 /$ sssaj2018.02.0082
Pagadala, S., Marine, S. C., Micallef, S. A., Wang, F., Pahl, D. M., Melendez, M. V., et al. (2015). Assessment of region, farming system, irrigation source and sampling time as food safety risk factors for tomatoes. Int. J. Food Microbiol. 196, 98-108. doi: 10.1016/j.ijfoodmicro.2014. 12.005

Pan, F., Li, X., Carabez, J., Ragosta, G., Fernandez, K. L., Wang, E., et al. (2015). Cross-sectional survey of indicator and pathogenic bacteria on vegetables sold from Asian vendors at farmers' markets in northern California. J. Food Prot. 78, 602-608. doi: 10.4315/0362-028X.JFP-14-095

Park, S., Navratil, S., Gregory, A., Bauer, A., Srinath, I., Szonyi, B., et al. (2015). Multifactorial effects of ambient temperature, precipitation, farm management, and environmental factors determine the level of generic Escherichia coli contamination on preharvested spinach. Appl. Environ. Microbiol. 81, 2635-2650. doi: 10.1128/AEM.03793-14

Park, S., Szonyi, B., Gautam, R., Nightingale, K., Anciso, J., and Ivanek, R. (2012). Risk factors for microbial contamination in fruits and vegetables at the preharvest level: a systematic review. J. Food Prot. 75, 2055-2081. doi: 10.4315/0362-028X.JFP-12-160

Partyka, M. L., Bond, R. F., Chase, J. A., and Atwill, E. R. (2018). Spatial and temporal variability of bacterial indicators and pathogens in six California reservoirs during extreme drought. Water Res. 129, 436-446. doi: 10.1016/j.watres.2017.11.038

Paton, A.W., and Paton, J. C. (1998). Detection and characterization of shiga toxigenic Escherichia coli by using multiplex PCR assays for stx1, stx2, eaeA, enterohemorrhagic E-coli hlyA, rfbO111, and rfbO157. J. Clin. Microbiol. 36, 598-602 doi: 10.1128/JCM.36.2.598-602.1998

Patterson, L., Navarro-Gonzalez, N., Jay-Russell, M. T., Aminabadi, P., AntakiZukoski, E., and Pires, A. F. A. (2018). Persistence of Escherichia coli in the soil of an organic mixed crop-livestock farm that integrates sheep grazing within vegetable fields. Zoonoses Public Health. 65, 887-896. doi: 10.1111/zph.12503

Pires, A. F. A., Patterson, L., Kukielka, E. A., Aminabadi, P., NavarroGonzalez, N., and Jay-Russell, M. T. (2019). Prevalence and risk factors associated with Campylobacter spp. and Salmonella enterica in livestock raised on diversified small-scale farms in California. Epidemiol. Infect. 147:e321. doi: $10.1017 /$ S095026881900205X

Pires, A. F. A., Millner, P. D., Baron, J., and Jay-Russell, M. T. (2018). Assessment of current practices of organic farmers regarding biological soil amendments of animal origin in a multi-regional US study. Food Prot. Trends. 38, 347-362. Available online at: https://www.foodprotection.org/publications/foodprotection-trends/archive/2018-09-assessment- of-current-practices- oforganic-farmers-regarding-biological-soil-amendments- of-a/

Pradhan, A.K., Pang, H., and Mishra, A. (2019). "Chapter 6: foodborne disease outbreaks associated with organic foods: animal and plant products," Safety and Practice for Organic Food, eds D. Biswas and S. A. Micallef, Cambridge, MA: Academic Press, 135-150. doi: 10.1016/B978-0-12-812060-6.00006-4

R Core Team (2020). R: A Language and Environment for Statistical Computing. Vienna: R Foundation for Statistical Computing.

Ramos, T. M., Jay-Russell, M. T., Millner, P. D., Shade, J., Misiewicz, T., Sorge, U. S., et al. (2019). Assessment of biological soil amendments of animal origin use, research needs, and extension opportunities in organic production. Front. Sustain. Food Syst. 3:73. doi: 10.3389/fsufs.2019.00073

Rosen, C. J., and Allan, D. L. (2007). Exploring the benefits of organic nutrient sources for crop production and soil quality. Horttechnology 17, 422-430. doi: 10.21273/HORTTECH.17.4.422

Rosen, C. J., and Bierman, P. M. (2005). How to manage soil and nutrients in home yards and gardens. Available online at: http://www.extension.umn.edu/garden/ fruit-vegetable/using-manure-and-compost/ (accessed February 8, 2016).

Schober, P., Boer, C., and Schwarte, L. A. (2018). Correlation coefficients: appropriate use and interpretation. Anesth Analg. 126, 1763-1768. doi: 10.1213/ANE.0000000000002864

Sharma, M., Millner, P. D., Hashem, F., Camp, M., Whyte, C., Graham, L., et al. (2016). Survival and persistence of non-pathogenic Escherichia coli and attenuated Escherichia coli $\mathrm{O} 157: \mathrm{H} 7$ in soils amended with animal manure in a greenhouse environment. J. Food Prot. 79, 913-921. doi: 10.4315/0362-028X.JFP-15-421

Sharma, M., Millner, P. D., Hashem, F., Vinyard, B.T., East, C. L., Handy, E. T., et al. (2019). Survival of Escherichia coli in manure-amended soils is affected by spatiotemporal, agricultural, and weather factors in the 
Mid-Atlantic United States. Appl. Environ. Microbiol. 85. e02392-e02318. doi: 10.1128/AEM.02392-18

Sharma, M., and Reynnells, R. (2016). Importance of soil amendments: survival of bacterial pathogens in manure and compost used as organic fertilizers. Microbiol. Spectr. 4. doi: 10.1128/microbiolspec.PFS-0010-2015

Sheng, L., Shen, X., Benedict, C., Su, Y., Tsai, H.-C., Schacht, E., et al. (2019). Microbial safety of dairy manure fertilizer application in raspberry production. Front. Microbiol. 10:2276. doi: 10.3389/fmicb.2019.02276

Sinton, L. W., Braithwaite, R. R., Hall, C. H., and Mackenzie, M. L. (2007). Survival of indicator and pathogenic bacteria in bovine feces on pasture. Appl. Environ. Microbiol. 73, 7917-7925. doi: 10.1128/AEM.01620-07

Strawn, L. K., Fortes, E. D., Bihn, E. A., Nightingale, K. K., Grohn, Y. T., Worobo, R. W., et al. (2013a). Landscape and meteorological factors affecting prevalence of three food-borne pathogens in fruit and vegetable farms. Appl. Environ. Microbiol. 79, 588-600. doi: 10.1128/AEM.02491-12

Strawn, L. K., Grohn, Y. T., Warchocki, S., Worobo, R. W., Bihn, E. A., and Wiedmann, M. (2013b). Risk factors associated with Salmonella and Listeria monocytogenes contamination of produce fields. Appl. Environ. Microbiol. 79, 7618-7627. doi: 10.1128/AEM.02831-13

Szymczak, B., Szymczak, M., Sawicki, W., and Dabrowski, W. (2014). Anthropogenic impact on the presence of $L$. monocytogenes in soil, fruits, and vegetables. Folia Microbiol. (Praha). 59, 23-29. doi: 10.1007/s12223-013-0260-8

Tautges, N. E., Chiartas, J. L., Gaudin, A. C. M., O'geen, A. T., Herrera, I., and Scow, K. M. (2019). Deep soil inventories reveal that impacts of cover crops and compost on soil carbon sequestration differ in surface and subsurface soils. Glob. Change Biol. 25, 3753-3766. doi: 10.1111/gcb.14762

United States Department of Agriculture National Agricultural Statistics Service (2014). 2014 Organic Survey in: 2012 Census of Agriculture. Washington, DC: UDOA Nass.

United States Department of Agriculture National Organic Program (2011a). "National organic program handbook: guidance and instructions for accredited certifying agents and certified operations," in Guidance: Processed Animal Manures in Organic Crop Production, ed A.M.S. United States Department of Agriculture (Washington, DC: National Organic Program).

United States Department of Agriculture National Organic Program (2011b). "Soil fertility and crop nutrient management practice standard," in: Fed. Reg 7, Subtitle B, Chapter I, Subchapter M, Part 205, ed N.O. Program (Washington, DC: USDA), 400-401.

Uyttendaele, M., Moneim, A., Ceuppens, S., and Tahan, F. (2014). Microbiological safety of strawberries and lettuce for domestic consumption in Egypt. J. Food Process. Technol. 5, 1-7 doi: 10.4172/2157-7110.10 00308

Weller, D., Wiedmann, M., and Strawn, L. K. (2015a). Irrigation is significantly associated with an increased prevalence of Listeria monocytogenes in produce production environments in New York state. J. Food Prot. 78, 1132-1141. doi: 10.4315/0362-028X.JFP14-584

Weller, D., Wiedmann, M., and Strawn, L. K. (2015b). Spatial and temporal factors associated with an increased prevalence of Listeria monocytogenes in spinach fields in New York state. Appl. Environ. Microbiol. 81, 6059-6069. doi: 10.1128/AEM.01286-15

Wright, D. (2018). Corrgram: Plot A Correlogram. R package version 1.13. Available online at: https://kwstat.github.io/corrgram/

You, Y., Rankin, S. C., Aceto, H. W., Benson, C. E., and Toth J. D., and Dou, Z. (2006). Survival of Salmonella enterica serovar Newport in manure and manure-amended soils. Appl. Environ. Microbiol. 72, 5777-5783 doi: 10.1128/AEM.00791-06

Zhu, Q., Gooneratne, R., and Hussain, M. A. (2017). Listeria monocytogenes in fresh produce: outbreaks, prevalence and contamination levels. Foods 6:21. doi: 10.3390/foods6030021

Conflict of Interest: The authors declare that the research was conducted in the absence of any commercial or financial relationships that could be construed as a potential conflict of interest.

Publisher's Note: All claims expressed in this article are solely those of the authors and do not necessarily represent those of their affiliated organizations, or those of the publisher, the editors and the reviewers. Any product that may be evaluated in this article, or claim that may be made by its manufacturer, is not guaranteed or endorsed by the publisher.

Copyright (C) 2021 Ramos, Jay-Russell, Millner, Baron, Stover, Pagliari, Hutchinson, Lilley, Rowley, Haghani, Aminabadi, Kenney, Hashem, Martínez-López, Bihn, Clements, Shade, Sciligo and Pires. This is an open-access article distributed under the terms of the Creative Commons Attribution License (CC BY). The use, distribution or reproduction in other forums is permitted, provided the original author(s) and the copyright owner(s) are credited and that the original publication in this journal is cited, in accordance with accepted academic practice. No use, distribution or reproduction is permitted which does not comply with these terms. 